Klinička psihologija 11 (2018), 1-2, 57-86

Pregledni članak - UDK 159.942.2

DOI: 10.21465/2018-KP-1-2-0004

\title{
EFEKTI I MEHANIZMI DJELOVANJA SAMOEFIKASNOSTI NA TJELESNO ZDRAVLJE
}

\author{
Igor Kardum \\ Odsjek za psihologiju, Filozofski fakultet, Sveučilište u Rijeci \\ Sveučilišna avenija 4, 51000 Rijeka \\ kardum@ffri.hr \\ Jasna Hudek-Knežević \\ Odsjek za psihologiju, Filozofski fakultet, Sveučilište u Rijeci \\ Sveučilišna avenija 4, 51000 Rijeka \\ hudekj@ffri.hr \\ Nada Krapić \\ Odsjek za psihologiju, Filozofski fakultet, Sveučilište u Rijeci \\ Sveučilišna avenija 4, 51000 Rijeka \\ nkrapic@ffri.hr
}

\begin{abstract}
Sažetak
U ovom su radu prikazani efekti samoefikasnosti na različite aspekte tjelesnog zdravlja kao i osnovni mehanizmi putem kojih samoefikasnost potencijalno može djelovati na zdravstvene ishode. U prvom su dijelu rada opisana teorijska ishodišta samoefikasnosti i načini mjerenja generalizirane i specifičnih samoefikasnosti. Nakon toga navedeni su najvažniji nalazi koji govore o efektima samoefikasnosti na različite aspekte tjelesnog zdravlja. Od mehanizama putem kojih samoefikasnost djeluje na tjelesno zdravlje opisano je njezino djelovanje na kardiovaskularno i imunološko funkcioniranje, doživljaj stresa i načine suočavanja sa stresom te zdravstvena ponašanja. Iako viša samoefikasnost u pravilu ima pozitivne efekte na tjelesno zdravlje, prikazana su i istraživanja koja pokazuju da viša samoefikasnost može djelovati na kardiovaskularno funkcioniranje i zdravstvena ponašanja tako da njezini efekti na tjelesno zdravlje potencijalno mogu biti i negativni. U radu su navedene i neke najvažnije smjernice za buduća istraživanja odnosa između samoefikasnosti i tjelesnog zdravlja.
\end{abstract}

Ključne riječi: samoefikasnost, tjelesno zdravlje, zdravstvena ponašanja, suočavanje sa stresom

Ovaj je članak nastao u okviru znanstvenog projekta pod nazivom "Ličnost, emocije i socijalni procesi kao odrednice zdravstvenih ishoda (13.04.1.2.01)", koji financira Sveučilište u Rijeci. 


\section{PERCEPCIJA VLASTITE EFIKASNOSTI I NJEZINO MJERENJE}

Polazeći od osnovnih principa socijalno-kognitivne teorije, konstrukt percipirane samoefikasnosti razvio je Bandura (1977). On se odnosi na percipiranu sposobnost djelovanja u specifičnim situacijama, odnosno na procjenu koliko efikasno možemo djelovati u određenom kontekstu i koliko efikasno možemo koristiti svoje kognitivne resurse (Bandura, 2014). Naime, za adaptivno funkcioniranje potrebna nam je relativno točna procjena vlastitih mentalnih i fizičkih kapaciteta. Precjenjivanje vlastitih sposobnosti može dovesti do beskorisnih ili čak opasnih ponašanja, dok podcjenjivanje dovodi do nepotrebnih ograničenja i propuštanja prilika za osobni razvoj. Točna ili malo precijenjena percepcija vlastitih sposobnosti omogućava nam izbor ciljeva koji su nam izazovni, ali dostižni i čije ostvarenje dovodi do osjećaja zadovoljstva, što dugoročno ima pozitivne učinke na razvoj ličnosti (Cervone, 2000; Higgins i Scholer, 2008). Osobe s višom percipiranom samoefikasnošću spremnije ulaze u izazovne situacije, u njima ulažu više napora, ustrajnije su i lakše podnose tjelesne i emocionalne neugodnosti. Dakle, percipirana samoefikasnost utječe na to koje ćemo aktivnosti poduzeti, koliko ćemo napora u njih uložiti i koliko ćemo ustrajati u njima. Drugačije razmišljamo i ponašamo se u situacijama u kojima smo sigurni u naše sposobnosti, a drugačije u situacijama u kojima se osjećamo nesigurno ili nekompetentno. Također, percepcija vlastite efikasnosti snažno djeluje i na naše emocionalne reakcije. Nedoumice oko toga možemo li se suočiti s nekom izazovnom situacijom dovode do osjećaja straha, prijetnje i povećanog fiziološkog uzbuđenja, pri čemu to nije posljedica objektivnih karakteristika podražaja ili situacija, nego razlike između percipirane razine naših sposobnosti i zahtjeva okoline (Bandura, 2014). Kod osoba s niskom percepcijom vlastite efikasnosti učestale su emocionalne reakcije anksioznosti i depresije. Anksioznost nastaje ne samo kao rezultat naše neefikasnosti da se ponašajno suočimo s prijetećim situacijama, nego i iz naše neefikasnosti da kontroliramo ili prekinemo tijek uznemirujućih misli, dok je depresija posljedica nemogućnosti ostvarenja vrijednih osobnih ciljeva (Higgins i Scholer, 2008). Dakle, percepcija vlastite efikasnosti utječe na mišljenje, motivaciju, emocije i emocionalno uzbuđenje pojedinca.

Percipirana samoefikasnost nije generalizirana dispozicija ličnosti, nego procjena vlastitih sposobnosti za uspješno djelovanje unutar nekog specifičnog područja. Ljudi obično imaju visoku percepciju vlastite efikasnosti za neka područja i nisku za neka druga. Teško je biti kompetentan ili nekompetentan za bilo koji aspekt ljudske djelatnosti. Čak i unutar istog područja procjene samoefikasnosti mogu biti vrlo različite, ovisno o situacijskim razlikama. Netko se npr. može osjećati vrlo sigurno i kompetentno dok predaje studentima, ali vrlo nesigurno i nekompetentno dok predaje grupi stručnjaka. Međutim, percepcija samoefikasnosti ne mora biti niti u potpunosti specifična. Ljudi mogu imati generalizirani osjećaj samoefikasnosti kroz cijeli niz aktivnosti koje doživljavaju funkcionalno povezanima, a osim toga prethodna uspješnost također može dovesti do generaliziranog osjećaja samoefikasnosti (Maddux i Gosselin, 2012). 
Socijalno-kognitivna teorija posebno se bavi i pitanjima razvoja percipirane samoefikasnosti. Ona pretpostavlja da je percepcija vlastite efikasnosti produkt kognitivnog procesiranja u kojem osoba izabire, interpretira i integrira informacije iz različitih izvora, pri čemu su najvažnije informacije o uspješnosti ili neuspješnosti u prethodnim aktivnostima i one koje su stečene opservacijskim učenjem, dok su manje važne informacije o vlastitom fiziološkom uzbuđenju i subjektivnim emocionalnim stanjima te povratne informacije koje dobivamo od drugih osoba (Maddux i Gosselin, 2012). Uspješnost u prethodnim aktivnostima najvažniji je izvor informacija o vlastitoj efikasnosti. Osobnim iskustvom pojedinac stječe najviše informacija o vlastitim prednostima i kompetencijama, kao i o vlastitim slabostima i ograničenjima. Uspješnost u prethodnim aktivnostima i percipirana samoefikasnost recipročno su povezane. Prethodni uspjeh povećava percepciju samoefikasnosti, a ona pak povećava vjerojatnost budućih uspjeha. Međutim, prethodna uspješnost ne dovodi uvijek i nužno do povećane percepcije samoefikasnosti. Ljudi ponekad misle da ne mogu ponoviti prethodne uspjehe, a ponekad da mogu učiniti i ono što još nikada nisu. Istraživanja pokazuju da percipirana samoefikasnost točnije predviđa buduća ponašanja nego uspješnost $u$ prethodnim aktivnostima (Maddux i Volkmann, 2010). Osim toga, slična prethodna postignuća mogu imati različite učinke na percepciju samoefikasnosti različitih osoba te mogu dovesti do velikih razlika u njezinoj specifičnosti odnosno generalnosti (Bandura, Reese i Adams, 1982).

Opažanje ponašanja drugih osoba omogućava nam da vidimo uspjehe i neuspjehe drugih, da procjenjujemo sebe u odnosu na njih te da u skladu s tim informacijama razvijamo vjerovanja o vlastitoj efikasnosti. Ova neizravna iskustva posebno su nam važna onda kada nemamo izravnog iskustva na temelju kojeg bismo procijenili vlastitu efikasnost i onda kada ono sadrži kontradiktorne ili nejasne informacije o našim sposobnostima. Međutim, za razvoj samoefikasnosti neizravno je iskustvo manje važno od izravnog. Subjektivna emocionalna stanja koja doživljavamo u specifičnim situacijama također nam pružaju informacije o percipiranoj samoefikasnosti. Npr. učestali osjećaji prijetnje i straha povezani s potencijalnim neuspjehom mogu negativno djelovati na samoefikasnost, dok osjećaj radosti zbog predviđanja uspjeha može djelovati pozitivno. Slično je i s percepcijom vlastitog fiziološkog uzbuđenja. Ponekad ljudi svoje povećano fiziološko uzbuđenje interpretiraju kao znak da se ne mogu nositi sa situacijom, a sposobnost smirivanja vlastitog uzbuđenja kao znak da su u mogućnosti udovoljiti zahtjevima situacije. Emocionalna stanja i fiziološko uzbuđenje relativno su slabi izvori informacija o samoefikasnosti jer nam malo govore o tome hoćemo li u nekoj situaciji biti uspješni ili nećemo, a slično je i sa stavovima i vjerovanjima koja drugi ljudi imaju o našim sposobnostima (Bandura, 2014).

Dvojna teorijska priroda percipirane samoefikasnosti, shvaćena s jedne strane kao situacijski specifična, a s druge strane kao generalizirana dispozicija ličnosti, odražava se i na njeno mjerenje. Iako se samoefikasnost najčešće mjeri situacijski specifičnim mjerama, konstruiran je i veći broj upitnika za mjerenje generalizira- 
ne samoefikasnosti. Neki autori (npr. Cervone, 2000) smatraju da ti upitnici imaju ozbiljne nedostatke jer se opisivanjem samoefikasnosti samo jednom vrijednošću zanemaruju različiti uzorci percipirane samoefikasnosti koji su karakteristični za svakog pojedinca. Takvim se pristupom implicitno podrazumijeva interindividualna stabilnost generalizirane samoefikasnosti, što nije u skladu s njenom varijabilnom prirodom. Osim toga, kako navode Ajzen i Fishbein (1977), da bismo odredili najbolje prediktore specifičnih namjera i ponašanja, treba se pridržavati principa kompatibilnosti, odnosno koristiti i specifične prediktore. Brojna su istraživanja pokazala da su globalne i generalizirane mjere slabiji prediktori nego specifične. Međutim, kao što je dobro poznato, psihologija je zainteresirana i za pojedinačna ponašanja u specifičnim situacijama, ali i za pravilnosti u ponašanju, konzistentne uzorke ponašanja i stabilne tendencije reagiranja. $\mathrm{S}$ tim u skladu, u nastojanju da konstruiraju generalizirane mjere samoefikasnosti više je istraživača pridonijelo i teorijskom razvoju samoefikasnosti kao globalnog konstrukta. Tako npr. Schwarzer i Fuchs (1996) smatraju da generalizirana samoefikasnost sadrži skup prošlih uspjeha koje pojedinac pripisuje sebi, pa je vjerojatnost uspjeha u nekom specifičnom zadatku posljedica generalizirane i situacijski specifične samoefikasnosti. Shelton (1990) pak pretpostavlja da vrijednosti koje pripisujemo specifičnim iskustvima utječu na stupanj u kojem specifična samoefikasnost doprinosi generaliziranoj samoefikasnosti, međutim, vrijedi i obratno, generalizirana samoefikasnost može biti izvor informacija koje ljudi koriste kada procjenjuju specifičnu samoefikasnost (Maddux i Volkmann, 2010). Zbog toga se može očekivati da generalizirana samoefikasnost utječe na ponašanja i namjere u specifičnim situacijama prvenstveno preko svog djelovanja na situacijski specifičnu samoefikasnost, iako će zbog principa kompatibilnosti situacijski specifična samoefikasnost biti bolji prediktor namjera i ponašanja nego generalizirana.

Povećani interes za generaliziranu samoefikasnost doveo je do razvoja niza skala za njezino mjerenje, pri čemu je jedna od najčešće korištenih Skala opće samoefikasnosti (General Self-Efficacy Scale, GSE, Schwarzer i Jerusalem, 1995). Ona se u početku sastojala od 20 čestica, da bi kasnije bila skraćena na 10, koje su zasićene jednim faktorom. Sadržaj čestica odnosi se na jačinu pojedinčevih uvjerenja da su njegove sposobnosti adekvatne za udovoljavanje zahtjevima novih i teških situacija te za savladavanje poteškoća (npr. "Mogu riješiti najveći dio problema ako uložim neophodan napor"). Ova je skala prevedena na brojne jezike i primijenjena u različitim kulturama, a dosadašnja istraživanja pokazuju da ona pouzdano i valjano mjeri jednodimenzionalnu samoefikasnost (Scholz, Dona, Sud i Schwarzer, 2002). Podaci koji se odnose na konstruktnu valjanost pokazuju da je samoefikasnost mjerena ovom skalom negativno povezana sa stanjima i crtama koje se negativno vrednuju, kao što su usamljenost, depresija, anksioznost, pesimizam, nisko samopoštovanje i bespomoćnost. Nasuprot tome, samoefikasnost je pozitivno povezana s onim karakteristikama koje se vrednuju pozitivno, kao što su samopoštovanje, motivacija postignuća, internalni lokus kontrole, optimizam te sa sklonošću da se stresne situ- 
acije više doživljavaju kao izazovne nego kao prijeteće (Kardum i Hudek-Knežević, 2012; Luszczynska, Scholz i Schwarzer, 2002).

Na području zdravstvene psihologije konstruirane su i brojne skale samoefikasnosti koje nisu toliko generalizirane kao GSE, ali ni potpuno specifične i koje se najčešće odnose na percipiranu samoefikasnost za uspostavljanje različitih oblika zdravstveno korisnih ponašanja te na samoefikasnost za suočavanje s različitim vrstama bolesti. Neki od primjera takvih skala jesu skale samoefikasnosti za tjelesno vježbanje u različitim uvjetima (Marcus, Selby, Niaura i Rossi, 1992), za zdravije navike ishrane (Rimal, 2000), za pridržavanje propisanog liječničkog tretmana (Chesney i sur., 2000), za suzdržavanje od pušenja (DiClemente, Prochaska i Gibertini, 1985) i alkohola (Goldbeck, Myatt i Aitchison, 1997), za sigurnije seksualno ponašanje (O'Leary, 2001), za preventivna ponašanja protiv AIDS-a (Kasen, Vaughan i Walter, 1992), za pacijente s kroničnom opstruktivnom bolešću pluća (Emme, Mortensen, Rydahl-Hansen, Ostergaard i Phanareth, 2012), za priznavanje statusa oboljelog od HIV-a i predlaganje sigurnijeg seksualnog ponašanja (Kalichman i sur., 2001), za rehabilitaciju nakon ortopedskih operacija (Waldrop, Lightsey, Ethington, Woemmel i Coke, 2001) te skale samoefikasnosti za pacijente oboljele od multiple skleroze (Airlie, Baker, Smith i Yong, 2001), epilepsije (Tedman, Thornton i Baker, 1995), artritisa (Lorig, Chastain, Ung, Shoor i Holman, 1989), karcinoma (Beckham, Burker, Lytle, Feldman i Costakis, 1997) itd.

U najvećem se broju istraživanja koriste situacijski specifične mjere samoefikasnosti, koje se najčešće sastoje od samo jedne čestice (npr. „Ako pokušate, koliko je vjerojatno da ćete prestati pušiti?"). Međutim, takva operacionalizacija samoefikasnosti također nije bez nedostataka. Uz psihometrijske probleme koji se pojavljuju u takvim slučajevima (npr. niska pouzdanost), treba naglasiti da ni takva operacionalizacija nije posve u skladu s izvornom teorijskom konceptualizacijom samoefikasnosti. Naime, da bismo ostvarili određeni cilj, potrebno je izvesti cijeli niz različitih ponašanja u različitim vremenskim točkama i ostvariti niz podciljeva. Samoefikasnost pojedinca za ostvarenje svakog podcilja može biti vrlo različita. Tako npr. netko može biti jako uvjeren da neće pušiti dok je sam ili u društvu nepušača, a znatno manje ako je u društvu pušača. Dakle, kada postoje različite komponente određenog ponašanja, za svaku od njih ljudi mogu imati različita mišljenja o vlastitoj efikasnosti. Cervone (2000) ističe da čak i kada se ispituje samo jedna aktivnost u nekom specifičnom kontekstu također mogu postojati različiti aspekti samoefikasnosti jer se bilo koji ponašajni akt može konceptualizirati na različite načine. Zbog toga mnogi istraživači smatraju da kod složenih ponašanja treba ispitivati više različitih aspekata samoefikasnosti. Ljudi o svakom od tih različitih aspekata samoefikasnosti najčešće razmišljaju u različitim vremenskim točkama, pa svaki od njih može biti vrijedan prediktor ishoda. Tako su npr. Stotland i Zuroff (1991) u programu kontrole tjelesne težine ispitivali tri aspekta samoefikasnosti - samoefikasnost za suočavanje sa specifičnim situacijama vezanim uz ishranu, zatim za pridržavanje pojedinih komponenti programa i samoefikasnost za ostvarenje ciljeva 
tretmana, tj. za gubitak određene tjelesne težine. Iako je korištenje višestrukih procjena korisna istraživačka strategija, takvo mjerenje samoefikasnosti također ima određenih nedostataka. Njime dobivamo skup mjera samoefikasnosti od kojih su neke povezane s ishodnim varijablama, a neke nisu. Međutim, kako ističe Cervone (2000), takva se mjerenja najčešće ne zasnivaju na nekom teorijskom okviru koji bi omogućio organizaciju različitih aspekata percepcije samoefikasnosti. U takvim je uvjetima onda teško identificirati pravo značenje pojedinih komponenti percipirane samoefikasnosti, jer oslanjanje samo na kriterij statističke značajnosti može dovesti do ignoriranja negativnih nalaza, kao i do toga da se po slučaju prenaglasi značenje pojedinih pozitivnih nalaza, a koji mogu biti samo posljedica korištenja višestrukih mjerenja. Npr. Schneider, O’Leary i Agras (1987) su na uzorku žena s bulimijom ispitali sedam aspekata samoefikasnosti, od kojih su samo tri bili značajni prediktori ishoda, tj. čestine uzimanja purgativa, dok je u prethodno spomenutom istraživanju Stotlanda i Zuroffa (1991) samo percipirana samoefikasnost za dostizanje ciljeva tretmana bila značajan prediktor gubitka tjelesne težine.

Da bi se otklonio ovaj nedostatak, predloženo je nekoliko heurističkih okvira za organizaciju višestrukih procjena samoefikasnosti. Cervone (2000) predlaže razlikovanje između percipirane samoefikasnosti za korištenje pojedinih strategija i percipirane samoefikasnosti za ostvarenje određenih ciljeva. Strategije ili planovi odnose se na način ostvarenja ciljeva, dok su ciljevi krajnji ishodi aktivnosti. Kada ljudi razmišljaju o svojoj efikasnosti u određenom području, oni se mogu usmjeriti ili na krajnji cilj koji žele ostvariti ili na načine kako će ga ostvariti. Npr. ispitanici u programu odvikavanja od pušenja mogu imati određenu percepciju vlastite efikasnosti za postizanje krajnjeg cilja, odnosno za prestanak pušenja i percepciju samoefikasnosti koja se odnosi na specifične strategije za ostvarenje tog cilja, npr. za korištenje strategije samoopažanja. S povećanjem iskustva i sigurnosti u primjeni pojedinih strategija raste i percipirana efikasnost za ostvarenje ciljeva. Budući da ljudi ne koriste specifične strategije bez toga da smatraju da mogu ostvariti određene ciljeve, percipirana samoefikasnost za ostvarenje određenih ciljeva može se smatrati medijatorom koji posreduje učinke samoefikasnosti za korištenjem pojedinih strategija na motivaciju za ostvarenjem specifičnih ciljeva (Maddux i Gosselin, 2012). Razlikovanje između samoefikasnosti za korištenjem pojedinih strategija i samoefikasnosti za ostvarenjem specifičnih ciljeva omogućava korištenje višestrukih procjena vlastite efikasnosti bez oslanjanja samo na empirijski kriterij statističke značajnosti i istovremeno omogućava operacionalizaciju samoefikasnosti u terminima dinamičkih kognitivnih procesa, a ne na razini apstraktne dispozicijske tendencije.

Sličan heuristički okvir predlažu Schwarzer i Renner (2000), koji naglašavaju razlikovanje između akcijske samoefikasnosti i samoefikasnosti suočavanja. Akcijska samoefikasnost važna je u periodu prije poduzimanja neke aktivnosti i ona se odnosi na percepciju vlastitih sposobnosti za postavljanjem izazovnih ciljeva $i$ poduzimanjem inicijative za njihovo ostvarenje. Pojedinci s visokom akcijskom samoefikasnošću lakše mogu zamisliti buduće uspješne događaje, predvidjeti po- 
tencijalne ishode različitih ponašajnih strategija i prihvatiti nova ponašanja. Samoefikasnost suočavanja važna je onda kada su već poduzeta ponašanja usmjerena prema ostvarenju nekog cilja i ona se odnosi na percepciju vlastitih sposobnosti za suočavanje s preprekama. Osobe s visokom samoefikasnošću suočavanja ulažu više napora u savladavanju prepreka i ustrajnije su u ostvarenju svojih ciljeva. Dakle, različiti aspekti samoefikasnosti mogu biti funkcionalni u različitim fazama samoregulacijskog, prema cilju usmjerenog ponašanja. Može se reći da je samoefikasnost složen konstrukt koji se može razlikovati i hijerarhijski (generalizirana, vezana uz neko područje aktivnosti, specifična), a što smo niže na toj hijerarhiji, očigledno je da mogu postojati i različite sekvence samoefikasnosti koje su temporalno i/ili funkcionalno organizirane s obzirom na specifične faze u ostvarenju određenih ciljeva. Očito je da je mjerenje samoefikasnosti od presudne važnosti za evaluaciju istraživanja odnosa samoefikasnosti i tjelesnog zdravlja te da je, ovisno o potrebi, nužno pronaći optimalnu razinu njegova mjerenja, što je ponekad vrlo teško jer ponašanje koje ispitujemo može biti pod utjecajem različitih samoefikasnosti na različitim hijerarhijskim razinama.

\section{PERCIPIRANA SAMOEFIKASNOST I ZDRAVSTVENI ISHODI}

Već neka starija istraživanja nalaze da osobe s niskom samoefikasnošću pokazuju manje preventivnih zdravstvenih ponašanja, da su manje optimistične u pogledu ranog tretmana bolesti, da svoje zdravlje procjenjuju lošijim i da imaju više epizoda bolesti (Seeman i Seeman, 1983). Novija istraživanja pokazuju da je percipirana samoefikasnost povezana s različitim zdravstvenim ishodima, kao što su mortalitet, fiziološke promjene koje se nalaze u podlozi nekih bolesti, subjektivni tjelesni simptomi, prilagodba na bolest, brzina oporavka, funkcionalni status nakon bolesti ili kirurške operacije i sl. (Bandura, 2014). Tako su npr. Kaplan, Ries, Prewitt i Eakin (1994) ispitivali u kojoj mjeri samoefikasnost može predvidjeti mortalitet kod bolesnika s kroničnom opstruktivnom bolešću pluća te su našli da je specifična samoefikasnost za hodanje značajan univarijatni prediktor petogodišnjeg preživljavanja. Također, percipirana samoefikasnost značajno predviđa različite objektivne pokazatelje plućnog funkcioniranja na osnovi kojih se može odrediti težina ove bolesti (Marino, Sirey, Raue i Alexopoulos, 2008).

Samoefikasnost je povezana i s nizom subjektivnih tjelesnih simptoma (Hudek-Knežević i Kardum, 2009). Nakon što su kontrolirani sociodemografski pokazatelji i stupanj doživljenog stresa, niža razina samoefikasnosti bila je povezana sa simptomima kronične iscrpljenosti (Findley, Kerns, Weinberg i Rosenberg, 1998), a kros-sekcijski i retrospektivni podaci dobiveni godinu dana nakon otpuštanja iz bolnice pokazali su da je viša samoefikasnost povezana s manjim brojem subjektivnih neuroloških simptoma kod pacijenata s ozljedom leđne moždine (Horn, Yoels, Wallace, Macrina i Wrigley, 1998). Meta-analitičko istraživanje pokazuje da je viša 
samoefikasnost zaštitni faktor od izgaranja na poslu kod nastavnika i zdravstvenih djelatnika (Shoji i sur., 2016). Nadalje, ona je povezana s boljom percepcijom tjelesnog zdravlja kod adolescenata koji su doživjeli traumatski događaj (Cheever i Hardin, 1999) i s boljim prihvaćanjem dijagnoze dijabetesa tipa 2 (Besen i Esen, 2012), dok je kod starijih osoba niska samoefikasnost više povezana sa strahom od smrti nego pokazatelji tjelesnog zdravlja, demografske karakteristike i stupanj socijalne podrške (Fry, 2003).

Percipirana samoefikasnost također je važan prediktor boli. Pri porođaju ona bolje predviđa ustrajnost u kontroli boli nego ostale varijable, uključujući i dužinu porođaja, značajno predviđa dužinu vremena koje žene tijekom porođaja provode bez uzimanja sredstava za analgeziju i općenito je negativno povezana s uzimanjem medikamenata tijekom porođaja (Manning i Wright, 1983). Stockman i Altmaier (2001) navode da žene s višom samoefikasnošću doživljavaju manji intenzitet boli pri porođaju, čak i kada se kontrolira njihova dob i intenzitet menstrualne boli. Osim toga, njihovi podaci pokazuju da žene s višom samoefikasnošću bol percipiraju drugačije, odnosno da manje intenzivnim doživljavaju kognitivne i emocionalne aspekte boli. Viša samoefikasnost povezana je sa smanjenim intenzitetom boli i kod pacijenata s reumatoidnim artritisom (Lorig i Gonzales, 1992).

Najveći broj istraživanja odnosa samoefikasnosti i zdravstvenih ishoda ispitivao je njezine učinke na oporavak od različitih bolesti. Waldrop i suradnici (2001) nalaze da je i nakon kontrole drugih važnih varijabli kao što su tjelesno funkcioniranje pri prijemu u bolnicu, dispozicijski optimizam, zdravstvena kompetentnost itd., samoefikasnost značajan prediktor oporavka nakon ortopedske operacije. Ewart, Taylor, Reese i DeBusk (1983) nalaze da se na osnovi percipirane samoefikasnosti bolje može predvidjeti funkcionalni oporavak pacijenata podvrgnutih kardiološkom kirurškom zahvatu nego na osnovi rezultata kardiološke procjene pri otpuštanju iz bolnice. Viša samoefikasnost također je povezana s boljim funkcionalnim statusom pacijenata kojima je ugrađena premosnica na koronarnoj arteriji (Carroll, 1995) te s njihovim bržim povratkom na posao (Fitzgerald, Becker, Celentano, Swang i Brinker, 1989). Osobe s višom samoefikasnošću pokazuju višu razinu aktivnosti nakon kardiološke kirurške intervencije (Gortner i Jenkins, 1990). Dakle, na osnovi percipirane samoefikasnosti značajno se može predvidjeti ishod rehabilitacijskog procesa nakon kirurške intervencije. Treba međutim napomenuti da se pozitivne povezanosti samoefikasnosti s brzinom i stupnjem oporavka nakon kirurških intervencija često dobivaju samo onda kada se u statističkim analizama ne kontrolira početna razina prilagodbe. Naime, parcijalne korelacije percipirane samoefikasnosti i naknadnih mjera prilagodbe, uz kontrolu njihove početne razine, često su znatno niže i/ili statistički neznačajne (Elizur i Hirsh, 1999). Osim toga, čini se da osjećaj samoefikasnosti u visokostresnoj situaciji, kao što je akutna postoperativna faza u kojoj pacijent nema osjećaj osobne kontrole nad događajima, nije povezan sa zdravstvenim ishodima. U takvim se situacijama znatno povećava važnost socijalne podrške koju pacijent dobiva od drugih osoba (Hobfoll, London i Orr, 1988). 
Kada se radi o kroničnim bolestima, brojna istraživanja pokazuju da je viša percipirana samoefikasnost povezana s boljim zdravstvenim ishodima i boljom prilagodbom na različite bolesti kao što su reumatoidni artritis (Dwyer, 1997), osteoartritis (Rejeski, Traven, Ettinger, McFarlane i Shumaker, 1996), karcinom dojke (Rottmann, Dalton, Christensen, Frederiksen i Johansen, 2010), fibromialgija (Buckelew, Murray, Hewett, Johnson i Huyser, 1995), dijabetes (O'Hea i sur., 2009), cistična fibroza (Bartholemew, Parcel, Swang i Czyzewski, 1993), multipla skleroza (Schmitt, Goverover, DeLuca i Chiaravalotti, 2014), bol u donjem dijelu leđa (Lackner, Carosella i Feuerstein, 1996), pretilost i kronična opstruktivna bolest pluća (Bonsaksen, Fagermonen i Lerdal, 2014). Kod adolescenata je povezana s pozitivnijim zdravstvenim ishodima kod cistične fibroze, dijabetesa (Casier i sur., 2013) i kožnih bolesti (Dalgard, Stern, Lien i Hauser, 2012). Edwards, Telfair, Cecil i Lenoci (2001) npr. nalaze da samoefikasnost predviđa neposrednu i dugotrajnu prilagodbu kod oboljelih od srpaste anemije. Odrasli bolesnici s nižom razinom samoefikasnosti izvještavaju o većem broju tjelesnih i psiholoških simptoma srpaste anemije, o većem intenzitetu boli i češćim posjetima liječniku nego oni koji imaju višu samoefikasnost. Slični su rezultati dobiveni i kros-sekcijski i longitudinalno, nakon dvanaest mjeseci praćenja. Iako su neka prethodna istraživanja na pacijentima s fibromialgijom i artritisom pokazala da ishodne varijable bolje predviđa promjena u samoefikasnosti nego njezina početna razina (npr. Buckelew i sur., 1996), ovo je pokazalo da su i početna razina i promjene u samoefikasnosti tijekom vremena povezane s promjenama u tjelesnoj simptomatologiji srpaste anemije, odnosno da obje varijable značajno predviđaju stupanj prilagodbe i to nakon kontrole demografskih karakteristika ispitanika. Slične su rezultate dobili Riazi, Thompson i Hobart (2004) na oboljelima od multiple skleroze. Naime, početna razina samoefikasnosti kao i njezina promjena tijekom šest tjedana rehabilitacije bili su nezavisni prediktori zdravstvenog statusa, $\mathrm{tj}$. veća početna samoefikasnosti i veće povećanje samoefikasnosti tijekom rehabilitacije bili su povezani s poboljšanom sposobnošću hodanja te s manjim intenzitetom tjelesnih i psiholoških simptoma multiple skleroze. Najviše dokaza o povezanosti samoefikasnosti s boljim zdravstvenim ishodima i boljom prilagodbom dobiveno je na oboljelima od artritisa (Marks, 2001). Tako npr. istraživanja pokazuju da samoefikasnost kod starijih osoba oboljelih od osteoartritisa značajno predviđa brzinu pokreta i sposobnost izvođenja različitih zadataka (Rejeski i sur., 1996) te da je kod oboljelih od artritisa ona bolji prediktor nesposobnosti nego intenzitet boli (Schiaffino, Revenson i Gibofsky, 1991). Kod oboljelih od reumatoidnog artritisa ponašanja vezana uz bol (npr. šepanje, bolni izraz lica) više su povezana sa samoefikasnošću nego s težinom bolesti, a viša samoefikasnost povezana je s manjim intenzitetom umora, koji se inače često pojavljuje kod osoba oboljelih od kroničnog artritisa (Marks, 2001). Viša samoefikasnost također je povezana s manjom funkcionalnom nesposobnošću kod starijih osoba koje pokazuju smanjeni tjelesni kapacitet (Mendes de Leon, Seeman, Baker, Richardson i Tinetti, 1996) te s boljom prilagodbom mjerenom stupnjem doživljenog stresa, intenzite- 
tom pozitivnih i negativnih emocija te ponašajnim disfunkcijama kod oboljelih od karcinoma (Beckham i sur., 1997).

Dakle, viša samoefikasnosti povezana je sa smanjenom tjelesnom simptomatologijom i poboljšanim psihosocijalnim funkcioniranjem kod oboljelih od različitih kroničnih bolesti. Osim toga, samoefikasnost je povezana s tijekom bolesti. Longitudinalna istraživanja pokazuju da u periodu od nekoliko mjeseci do nekoliko godina viša samoefikasnost ima povoljan učinak na pacijente s kardiološkim bolestima, artritisom, karcinomom, fibromialgijom, kod starijih osoba i osoba kojima je ugrađeno umjetno koljeno ili kuk (Edwards i sur., 2001; Hartley, Vance, Elliott, Cuckler i Berry, 2008; Simpson i Jones, 2013). Nadalje, povezanost samoefikasnosti s funkcionalnim kapacitetom osoba oboljelih od kroničnih bolesti i s brzinom njihova oporavka često je nezavisna od težine bolesti i/ili razine tjelesnog oštećenja (Orbell, Johnson, Rowley, Davey i Espley, 2001).

\section{MEHANIZMI POVEZANOSTI SAMOEFIKASNOSTI SA ZDRAVSTVENIM ISHODIMA}

\section{Percipirana samoefikasnost i kardiovaskularno funkcioniranje}

Teorijski, percipirana samoefikasnost za suočavanje sa stresnim podražajima trebala bi imati zaštitnu funkciju pri fiziološkom odgovoru na stres. Naime, polazeći od transakcijskog modela stresa i suočavanja (Lazarus i Folkman, 1984), percipirana samoefikasnost zapravo predstavlja sekundarnu procjenu, važan osobni resurs za suočavanje s potencijalnom prijetnjom (Bandura, 2014). Osobe koje smatraju da posjeduju adekvatne resurse za uspostavljanjem kontrole nad stresnim podražajem tako da izbjegnu njegove štetne učinke, svakako bi trebale biti manje anksiozne i pokazivati smanjene fiziološke odgovore na stresni podražaj (Maddux i Gosselin, 2012). Dosadašnja istraživanja u velikoj mjeri potvrđuju ove pretpostavke. Naime, percipirana neefikasnost pri kontroli psiholoških stresnih podražaja povezana je s višim doživljajem stresa, autonomnom aktivacijom i izlučivanjem katekolamina (Bandura i sur., 1982; Bandura, Taylor, Williams, Mefford i Barchas, 1985; Hilmert, Christenfeld i Kulik, 2002). Općenito, stresne reakcije su smanjene kada se ljudi suočavaju sa stresnim podražajima koji su unutar njihova raspona samoefikasnosti, dok percipirana neefikasnost suočavanja dovodi do povećanja subjektivnog doživljaja stresa i fiziološke aktivacije. Takvi su efekti dobiveni i za biokemijske indikatore simpatičko-adrenalne aktivnosti kao što su adrenalin i noradrenalin (Bandura i sur., 1985), kao i za aktivnost njihovih ciljnih organa, što se npr. ogleda u pulsu, sistoličkom i dijastoličkom krvnom tlaku (Bandura i sur., 1982). Zanimljivo je da nakon što se percipirana samoefikasnost suočavanja poveća na maksimalnu razinu, suočavanje s prethodno prijetećim stresnim podražajem više ne izaziva povi- 
šenu fiziološku aktivaciju (Wiedenfeld i sur., 1990). Istraživanja nadalje pokazuju da je oporavak od infarkta miokarda brži kada su pacijent i njegov bračni partner uvjereni u pacijentove kardijalne kapacitete (Taylor, Bandura, Ewart, Miller i DeBusk, 1985), da je tjelesno funkcioniranje pacijenata s koronarnom bolešću srca šest mjeseci nakon kardiološke intervencije bolje kod osoba s višom kardijalnom samoefikasnošću (Sullivan, LaCroix, Russo i Katon, 1998) te da je niža razina samoefikasnosti povezana s lošijim kardiološkim funkcioniranjem kod pacijenata s kardiovaskularnim bolestima (Sarkar, Ali i Whooley, 2009; Steca i sur., 2013). Craig i suradnici (2001) su pokazali da je trening smanjenja krvnog tlaka putem biofeedbacka u kućnim uvjetima efikasniji kod osoba s višom samoefikasnošću. Istraživanje na nastavnicima pokazalo je da je viša samoefikasnost povezana s povišenim kardiološkim reakcijama tijekom nastave, povišenim pozitivnim afektom u školi, nižim izgaranjem na poslu, manjim brojem kardioloških smetnji i nižom razinom jutarnjeg kortizola (Schwerdtfeger, Konermann i Schonhofen, 2008), što je u skladu sa shvaćanjem samoefikasnosti kao adaptivnog resursa s potencijalno pozitivnim zdravstvenim posljedicama (Banik, Schwarzer, Knoll, Czekierda i Luszczynska, 2018).

Međutim, visoka samoefikasnost u određenim uvjetima može dovesti i do lošijih zdravstvenih posljedica. To se prije svega odnosi na one situacije kod kojih pojedinac nema kontrolu nad ishodima. Wortman i Dunkel-Schetter (1979) npr. navode da se osobe oboljele od karcinoma koje imaju visoku percipiranu samoefikasnost više okrivljuju za narušeno tjelesno funkcioniranje, nad kojim zapravo nemaju nikakvu kontrolu, nego osobe s niskom percipiranom samoefikasnošću. U nekoliko istraživanja dobiveni su slični efekti samoefikasnosti i na kardiovaskularnu reaktivnost. Schaubroeck i Merritt (1997) nalaze da kod osoba s visokom samoefikasnošću visoki stupanj kontrole smanjuje negativne stresne posljedice visokih zahtjeva posla. Međutim, kada je kontrola niska, kod osoba s visokom samoefikasnošću dolazi do povećanja sistoličkog i dijastoličkog krvnog tlaka. Nasuprot tome, kod osoba s niskom samoefikasnošću visoki zahtjevi posla povezani su s povišenim krvnim tlakom kada je kontrola visoka. Slični su rezultati dobiveni i u laboratorijskim uvjetima. Gerin, Litt, Deich i Pickering (1995) su pronašli interakcijski efekt kontrole i percipirane samoefikasnosti na sistolički i dijastolički krvni tlak i puls, pri čemu u uvjetu visoke kontrole ispitanici s niskom samoefikasnošću za izvođenje zadatka mentalne aritmetike imaju značajno više sve indekse kardiovaskularne reaktivnosti u usporedbi s ispitanicima koji imaju visoku samoefikasnost. I neke druge varijable slične kontroli mogu moderirati učinke percipirane samoefikasnosti na kardiovaskularnu reaktivnost. Wright i Dismukes (1995) navode da je kod osoba niske samoefikasnosti kardiovaskularna reaktivnost veća kada je zadatak lagan, dok je kod osoba s visokom samoefikasnošću ona veća kada je zadatak težak. Sanz i Villamarin (2001) nalaze da su efekti percipirane samoefikasnosti na kardiovaskularnu reaktivnost veći kada se posljedice neuspjeha u zadatku doživljavaju važnijima. Dakle, osobe $\mathrm{s}$ višom percipiranom samoefikasnošću u nekim uvjetim mogu pokazivati 
veću kardiovaskularnu reaktivnost nego osobe s niskom samoefikasnošću. Neki autori (npr. Gerin, Litt, Deich i Pickering, 1996) smatraju da se samoefikasnost može shvatiti kao dio aktivnog suočavanja sa stresom. Oni, naime, smatraju da se aktivno suočavanje sastoji od dvije komponente: percipirane sposobnosti (samoefikasnosti) i težine zadatka. Povećana kardiovaskularna reaktivnost može dijelom biti posljedica napora koji osobe s višom samoefikasnošću ulažu u aktivno suočavanje sa stresnom situacijom, a dijelom nepodudarnosti između percipiranih sposobnosti i zahtjeva situacije (npr. visoka samoefikasnost-niska kontrola). Dakle, čini se da je odnos između samoefikasnosti i njegovih fizioloških posljedica puno složeniji nego što su pokazala početna istraživanja te da on može ovisiti o vrsti fizioloških varijabli koje ispitujemo (npr. puls, sistolički ili dijastolički krvni tlak, temperatura kože), vrsti izazova (npr. razina kontrole, stabilnost ishoda), poticajima prisutnim pri izvedbi zadataka, pa čak i o tome koja je publika prisutna (npr. stručnjaci ili laici) (Schwerdtfeger i sur., 2008). U svakom slučaju, potrebna su detaljnija istraživanja efekata percipirane samoefikasnosti na kardiovaskularnu reaktivnost, posebno kada znamo da su osobe koje na standardizirane laboratorijske stresne podražaje pokazuju povećanu kardiovaskularnu reaktivnost sklonije visokom krvnom tlaku, koji je pak jedan od najvažnijih faktora za razvoj srčanih bolesti, moždanog udara i bolesti bubrega te koji je pozitivno povezan s mortalitetom (Light, Sherwood i Turner, 1992).

\section{Percipirana samoefikasnost i imunološko funkcioniranje}

Istraživanja odnosa između percipirane samoefikasnosti i imunološkog funkcioniranja relativno su rijetka, a ona uglavnom pokazuju da viša razina pericipirane samoefikasnosti ima povoljan učinak na imunološki status. Međutim, ima i istraživanja koja to ne potvrđuju. Na uzorku muškaraca zaraženih HIV-om Woods, Antoni, Ironson i Kling (1999) nisu našli povezanost percipirane samoefikasnosti i imunološkog statusa operacionaliziranog brojem i postotokom T-pomagačkih stanica. Guidi i suradnici (1999) također ne nalaze povezanost samoefikasnosti i imunoloških promjena tijekom stresnog ispitnog perioda kod studenata medicine.

O'Leary, Shoot, Lorig i Holman (1988) su na grupi pacijentica s reumatoidnim artritisom ispitivali efekte kognitivno-bihevioralne terapije, koja je bila usmjerena na usvajanje vještina upravljanja stresom, boli i ostalim simptomima bolesti. Njihovi su rezultati pokazali da takav tretman dovodi do povećanja percipirane samoefikasnosti te da na kraju tretmana ispitanice s višom samoefikasnošću i one kojima se samoefikasnost više povećala tijekom tretmana imaju veći broj supresorskih T-stanica i manji omjer pomagačkih/supresorskih T-stanica. Neka su istraživanja pokazala da percipirana samoefikasnost ima pozitivan učinak na imunološko funkcioniranje, ali u interakciji s ostalim tjelesnim sustavima uključenim u stresnu transakciju. Tako su npr. Bandura, Cioffi, Taylor i Brouillard (1988) pokazali da percepcija niske samoefikasnosti u uspostavljanju kontrole nad stresnim podražajem 
aktivira izlučivanje endogenih opioida. Taj je nalaz naročito važan zato što su neki imunosupresivni efekti neefikasnosti pri kontroli stresnih podražaja posredovani upravo izlučivanjem endogenih opioida. Naime, kada se opioidni mehanizmi blokiraju, neefikasnost suočavanja pri djelovanju nekog stresnog podražaja više nema imunosupresivni učinak (Shavit i Martin, 1987).

Wiedenfeld i suradnici (1990) su ispitivali utjecaj eksperimentalno varirane percipirane samoefikasnosti suočavanja na imunološko funkcioniranje, pri čemu je kao stresni podražaj korišten tretman fobija od zmija. Mjerenja su izvedena u tri navrata: tijekom inicijalne faze u kojoj ispitanici nisu izlagani stresnom podražaju, tijekom faze povećanja samoefikasnosti u kojoj je primijenjena bihevioralna terapija i tijekom faze maksimalne samoefikasnosti. Dobiveni su rezultati pokazali da percipirana samoefikasnost u uspostavljanju kontrole nad stresnim podražajem posreduje imunološke promjene i na razini humoralnog i na razini staničnog imuniteta. Općenito, povećanje percipirane samoefikasnosti kontrole nad stresnim podražajem dovodi do poboljšanja imunološkog funkcioniranja mjerenog povećanjem broja različitih vrsta limfocita. Rezultati ovog istraživanja također su pokazali da i brzina kojom se uspostavlja percipirana samoefikasnost utječe na imunološki status. Sporije povećanje samoefikasnosti tijekom tretmana ima imunosupresivni učinak tijekom faze povećanja samoefikasnosti, dok je brže povećanje samoefikasnosti pozitivno povezano sa zadržavanjem poboljšane razine imunološkog funkcioniranja kada se postigne najviša razina samoefikasnosti. Autori smatraju da je brzo povećanje percipirane samoefikasnosti povezano s aktivacijom simpatičkog živčanog sustava, a sporo s adrenokortikalnom aktivacijom. U skladu s tim, opažene imunološke promjene kod osoba koje brzo razvijaju samoefikasnost determinirane su izlučivanjem katekolamina, a kod osoba koje sporo razvijaju percipiranu samoefikasnost kortizolom, koji općenito ima imunosupresivni učinak. Kod žena oboljelih od AIDS-a povećanje specifične samoefikasnosti vezane uz tu bolest tijekom tromjesečnog perioda bilo je značajno povezano s povećanjem broja CD4 stanica i smanjenjem virusnog opterećenja (Ironson i sur., 2005), dok je kod žena i muškaraca oboljelih od AIDS-a samoefikasnost pridržavanja liječničkih uputa i uzimanja lijekova imala izravan efekt na smanjenje virusnog opterećenja, ali ne i na broj CD4 stanica (Parsons, Rosof i Mustanski, 2008). Kod oboljelih od karcinoma prostate veća samoefikasnost bila je povezana s većim brojem NK stanica (Yang i sur., 2018). Čini se da samoefikasnost može imati pozitivan učinak na imunološko funkcioniranje i kod djece u preadolescentnoj dobi. Kroz tri mjerenja tijekom godine dana viša percipirana samoefikasnost bila je konzistentno povezana s nižom koncentracijom interleukina 6 u plazmi (Caserta, Wyman, Wang, Moynihan i O'Connor, 2011).

Usprkos tome što ova istraživanja pokazuju da percipirana samoefikasnost može djelovati na imunološko funkcioniranje, još uvijek nema istraživanja koja bi pokazala da su imunološke promjene posrednici u vezi između samoefikasnosti i tjelesnih bolesti. Najbliže tome je istraživanje koje su izveli Schaubroeck, Jones 
i Xie (2001), koji su ispitivali učinke zahtjeva posla, percepcije kontrole i samoefikasnosti na respiratorne infekcije i imunološko funkcioniranje mjereno razinom imunoglobulina A (IgA). Njihovi su rezultati pokazali da visoka percepcija kontrole smanjuje povezanost između zahtjeva posla i lošijeg zdravlja kod osoba s visokom percipiranom samoefikasnošću, odnosno dovodi do povećanja te povezanosti kod osoba s percipiranom neefikasnošću. Pri tome su ovakvi rezultati dobiveni i za respiratorne infekcije i za IgA. Međutim, ograničenje ovog istraživanja je u tome što ono nije longitudinalno i što zbog toga izravno ne testira medijacijsku ulogu $\operatorname{IgA~u}$ vezi između stresa na poslu i bolesti, nego su i IgA i respiratorne infekcije mjerene u jednoj vremenskoj točki kao različiti indikatori osjetljivosti na infektivne bolesti.

Percipirana samoefikasnost, doživljaj stresa i suočavanje sa stresom

Dosadašnja istraživanja izvedena na različitim uzorcima ispitanika i stresnih situacija uglavnom jednoznačno pokazuju da su percipirana samoefikasnost i samoefikasnost suočavanja važne determinante i doživljaja stresa i suočavajućih ponašanja. Tako npr. Matsushima i Shiomi (2003) nalaze da je socijalna samoefikasnost adolescenata negativno povezana s doživljajem interpersonalnog stresa te pozitivno sa sklonošću za suočavanjem s interpersonalnim stresom, dok van den Heuvel, de Witte, Schure, Sanderman i de Jong (2001) navode da osobe s višom samoefikasnošću suočavanja koje njeguju pacijente koji su preživjeli moždani udar imaju manji doživljaj stresa. Istraživanja sa stresnim situacijama na radnom mjestu pokazuju da osobe koje su sigurne u svoje sposobnosti izvođenja zadatka također koriste efikasnije načine suočavanja i doživljavaju manji intenzitet stresa (Park i Lee, 2015). Osobe s višom samoefikasnošću češće koriste suočavajuće strategije kojima nastoje prevenirati stresne podražaje (npr. unaprijed planiraju svoje radne obaveze) (Keoske, Kirk i Keoske, 1993). Rezultati dobiveni na zdravim ispitanicima također pokazuju da je niža samoefikasnost povezana s češćim korištenjem emocijama usmjerenih strategija suočavanja (Terry, 1994), suočavanja izbjegavanjem (Benight i sur., 1999; Rippetoe i Rogers, 1987), kao i s doživljajima anksioznosti i stresa (Bandura, 2014; Karademas i Kalantzi-Azizi, 2004; Roddenberry i Renk, 2010). O povezanosti suočavanja i samoefikasnosti svjedoče i istraživanja koja pokazuju da treninzi poboljšanja vještina suočavanja sa specifičnim stresnim situacijama mogu dovesti do povećanja specifične i generalizirane samoefikasnosti (Weitlauf, Smith i Cervone, 2000) te da treninzi usmjereni povećanju samoefikasnosti dovode i do efikasnijeg suočavanja (Gattuso, Litt i Fitzgerald, 1992).

Uloga samoefikasnosti i samoefikasnosti suočavanja posebno je važna u traumatskim situacijama. Tako je npr. globalna samoefikasnost negativno povezana s doživljajem stresa i objašnjava $25 \%$ varijance oporavka kod osoba koje su bile ugrožene erupcijom vulkana Mount St. Helens (Murphy, 1987). Niska samoefikasnost suočavanja kod izraelskih vojnika koji su sudjelovali u ratnim operacijama 
bila je povezana $\mathrm{s}$ intenzivnijim simptomima posttraumatskog stresnog poremećaja i doživljaja stresa dvije godine nakon vojnog sukoba (Solomon, Benbenishty i Mikulincer, 1991). Benight i suradnici (1997) nalaze da nakon prolaska uragana specifična samoefikasnost kod muškaraca s HIV-om objašnjava $51 \%$ varijance posttraumatskog stresnog poremećaja i $27 \%$ varijance doživljenog stresa, i to nakon kontrole varijabli kao što su strah od smrti, broj CD4 stanica, procijenjene štete, prihoda i obrazovanja. Slični su rezultati dobiveni na zdravim ispitanicima koji su preživjeli eksploziju u Oklahoma Cityju, gdje nakon kontrole stupnja prijetnje, prihoda, socijalne podrške i gubitka resursa samoefikasnost suočavanja objašnjava $28 \%$ varijance posttraumatskih stresnih simptoma (Benight i sur., 2000). Kod osoba izloženih djelovanju uragana Andrew, uz percepciju gubitka resursa specifična samoefikasnost suočavanja i suočavajuća ponašanja najbolje objašnjavaju psihološki doživljaj stresa godinu dana kasnije (Benight i sur., 1999). Osim toga, nakon preživljene prirodne katastrofe niska samoefikasnost suočavanja posreduje longitudinalne učinke akutnog stresnog odgovora na razvoj simptoma posttraumatskog stresnog poremećaja, dok je visoka samoefikasnost trenutno i odloženo pozitivno povezana s oporavkom od traume (Benight i Harper, 2002). Izloženost traumatskim i stresnim životnim događajima može imati negativne efekte na samoefikasnost, međutim, ona je važniji faktor za posttraumatsku adaptaciju nego izloženost traumi, broj stresnih događaja i percepcija gubitaka (Luszczynska i sur., 2009). Meta-analitičko istraživanje o zdravstvenim učincima samoefikasnosti nakon kolektivnih traumatskih događaja nalazi njegove umjerene do snažne efekte na doživljaj stresa i intenzitet $i$ čestinu simptoma posttraumatskog stresnog poremećaja u kros-sekcijskim istraživanjima te snažne efekte na doživljaj stresa i intenzitet simptoma posttraumatskog stresnog poremećaja u longitudinalnim istraživanjima (Luszczynska, Benight i Cieslak, 2009).

Kod bolesnika oboljelih i od kroničnih i akutnih bolesti viša samoefikasnost povezana je s češćim korištenjem adaptivnijih, na-problem-usmjerenih i s manjim korištenjem na-emocije-usmjerenih strategija suočavanja (Endler, Kocovski i Macrodimitris, 2001; Kraaij i sur., 2008). Gattuso i suradnici (1992) nalaze da viša samoefikasnost dovodi do boljeg ponašajnog i samoprocijenjenog suočavanja s endoskopijom te da stilovi suočavanja moderiraju efekte samoefikasnosti na specifično suočavanje s endoskopijom. Istraživanje psihološke prilagodbe nakon pobačaja pokazuje da se žene sa snažnijim osjećajem samoefikasnosti rjeđe prestaju prerano suočavati i češće fleksibilno primjenjuju nove strategije suočavanja u situacijama kada je početna strategija bila neuspješna (Cozzarelli, 1993).

Istraživanja također pokazuju da su suočavanja sa stresnim situacijama jedan od mehanizama putem kojih samoefikasnost djeluje na različite zdravstvene ishode (Bandura, 2014; Hudek-Knežević i Kardum, 2006). Tako npr. strategije uočavanje posreduju učinke samoefikasnosti na samoprocijenjene tjelesne i mentalne simptome (Chemers, Hu i Garcia, 2001). Rippetoe i Rogers (1987) nalaze da viša samoefikasnosti za izvođenje preporučenog oblika zdravstvenog ponašanja (samo- 
pregledavanje grudi) povećava namjeru za korištenjem tog oblika ponašanja, što je dijelom posredovano racionalnim, na-problem-usmjerenim strategijama suočavanja. Na uzorku starijih osoba oboljelih od osteoartritisa Miller i Cronan (1998) nalaze da na-problem-usmjereno suočavanje ima pozitivan, a na-emocije-usmjereno suočavanje negativan učinak na njihov zdravstveni status te da viša samoefikasnost posreduje više na-problem i niže na-emocije-usmjereno suočavanje.

Treba napomenuti da neka istraživanja pokazuju da percipirana samoefikasnost sama za sebe ne dovodi uvijek do bolje psihološke prilagodbe nakon djelovanja stresnog podražaja (npr. Jex i Bliese, 1999). Kako navode ovi autori, visoki osjećaj samoefikasnosti znači samo da osoba vjeruje da posjeduje kompetencije za izvođenje određenih ponašanja. Iako je već samo to uvjerenje često dovoljno za ublažavanje negativnog djelovanja stresnih podražaja, njegov je učinak slabiji ako nije praćen i efikasnijim stilovima suočavanja. Ispitujući moderatorski efekt stilova suočavanja na odnos između samoefikasnosti i psihološke napetosti uzrokovane djelovanjem stresnih podražaja, Jex, Bliese, Buzzell i Primeau (2001) nalaze da visoka samoefikasnost smanjuje štetne učinke stresnih podražaja na psihološku prilagodbu onda kada ispitanici koriste aktivno suočavanje i kada ne koriste suočavanje izbjegavanjem.

Dakle, percipirana samoefikasnost i samoefikasnost suočavanja znatno poboljšavaju našu prilagodbu pri djelovanju stresnih podražaja, jer smanjuju doživljaja stresa $\mathrm{i} /$ ili dovode do efikasnijih strategija suočavanja. Međutim, još uvijek nije jasan mehanizam kojim se to događa. Jednu mogućnost iznose Bandura i suradnici (1988), koji pretpostavljaju da percipirana samoefikasnost može služiti kao kognitivni mehanizam putem kojeg ostali osobni resursi utječe na reakcije na stres. Drugim riječima, oni smatraju da dispozicijske varijable kao što su optimizam, lokus kontrole i čvrstoća ličnosti u stresnim situacijama djeluju tako da povećavaju osjećaj samoefikasnosti. Navedene dispozicijske varijable odnose se na općenite procjene nečijih sposobnosti i kapaciteta te zbog toga one mogu doprinositi procjenama specifične samoefikasnosti u velikom broju različitih situacija. Time se djelomično može objasniti i njihov utjecaj na različite vrste reakcija na stres. Međutim, iako se dispozicijski resursi mogu koristiti u različitim situacijama i okolnostima, njihova im općenitost smanjuje vjerojatnost manifestiranja odgovora koji bi se precizno poklapali sa zahtjevima pojedine stresne situacije, kao što je to slučaj sa situacijski specifičnim osjećajem samoefikasnosti (Kardum i Hudek-Knežević, 2008). Zbog toga što predstavlja vrlo specifično vjerovanje o osobnim kapacitetima, odnosno specifičnu kognitivnu procjenu sposobnosti da se postigne željeni cilj u određenoj situaciji, osjećaj samoefikasnosti može motivirati efikasna suočavajuća ponašanja koja su izravno usmjerena na specifičnu stresnu situaciju (Maddux i Gosselin, 2012). Nadalje, pozitivni dispozicijski resursi povezani su s većom sposobnošću razvoja i korištenja socijalne podrške (Aspinwall i Taylor, 1992; Krapić, Hudek-Knežević i Kardum, 2015), koja je pak povezana s povećanom samoefikasnošću. Major i suradnici (1990) su npr. našli da percipirana socijalna podrška 
partnera, obitelji i prijatelja povećava osjećaj samoefikasnosti za suočavanje nakon pobačaja. Dakle, jedan od najznačajnijih doprinosa dispozicija ličnosti u kontekstu suočavanja sa stresnim događajima mogao bi biti u tome da one pomažu pojedincu da manifestira prikladan i/ili kontinuirani suočavajući odgovor putem povećanja osjećaja samoefikasnosti.

\section{Percipirana samoefikasnost i zdravstvena ponašanja}

Brojna istraživanja pokazuju da je percipirana samoefikasnost snažno povezana s različitim oblicima zdravstvenih ponašanja te da su ona jedan od najvažnijih mehanizama putem kojih samoefikasnost djeluje na zdravstvene ishode. Jedno od područja u kojem je samoefikasnost često ispitivana je seksualno ponašanje. Općenito, rezultati tih istraživanja pokazuju da viša percepcija samoefikasnosti za prihvaćanje sigurnijih oblika seksualnog ponašanja utječe i na češće manifestiranje takvih ponašanja. Teng i Mak (2011) su našli da je samoefikasnost važan prediktor prihvaćanja i održavanja sigurnijeg seksualnog ponašanja kod homoseksualaca. Kod osoba s HIV-om viša specifična samoefikasnost za dogovor s partnerom o upotrebi kondoma uzročno je povezana s njihovim češćim korištenjem (The NIMH Multisite HIV Prevention Trial Group, 2001). Studenti koji se percipiraju efikasnim kupiti i koristiti kondome te koji se efikasno dogovaraju s partnerom oko njihova korištenja stvarno ih češće i koriste (Brafford i Beck, 1991). Viša percepcija samoefikasnosti dogovaranja o upotrebi kondoma i kontroli seksualnih impulsa značajno je povezana s brojem rizičnih seksualnih odnosa tijekom sljedećih godinu dana (O'Leary, Jemmott i Jemmott, 2008). Srednjoškolci s nižom samoefikasnošću za neprihvaćanjem seksualnog odnosa imaju dva puta veću vjerojatnost seksualnog odnosa nego oni s višom, a oni s niskom samoefikasnošću za ispravnim i dosljednim korištenjem kondoma imaju pet puta veću vjerojatnost njegova nedosljednog korištenja. Ti su odnosi značajni i nakon što se kontroliraju efekti vjerovanja vezanih uz AIDS (Kasen i sur., 1992). Dakle, niže specifične samoefikasnosti vezane uz seksualno ponašanje dovode do rizičnih oblika ponašanja, često povezanih s AIDS-om. Isto vrijedi i za neke druge oblike seksualnog ponašanja, kao što je npr. korištenje kontracepcije (O’Leary, 1992), a važno je napomenuti da je viša samoefikasnost važna ne samo za promjenu nepoželjnog (O'Leary i sur., 2008), nego i za održavanje novousvojenog poželjnog oblika seksualnog ponašanja (Reid i Aiken, 2011).

Samoefikasnost je značajno povezana i s pušenjem, odnosno s prestankom pušenja i recidivom. Njezina se uloga najčešće ispituje u okviru bihevioralnih i kognitivno-bihevioralnih tretmana čiji je cilj prestanak pušenja. Ti su programi kratkotrajno najčešće vrlo efikasni, međutim, tijekom dužeg vremena visoki je postotak recidiva. Obično se u tim istraživanjima najprije odrede situacije ili afektivna stanja u kojima postoji velika vjerojatnost da se osoba neće moći suzdržati od pušenja. Na kraju tretmana ispitanici za svaku takvu situaciju procjenjuju stupanj sigurnosti da 
će se moći suzdržati od pušenja i takav agregirani rezultat samoefikasnosti koristi se za predviđanje ne/pušenja tijekom određenog perioda praćenja. U najvećem broju slučajeva taj skor ima visoku prediktivnu vrijednost za kasnije pušenje, odnosno viša samoefikasnost povezana je s dužim vremenom apstinencije (DiClemente i sur., 1985; Gwaltney, Metrik, Kahler i Shiffman, 2009). Istraživanja također pokazuju da su situacije za koje ispitanici procjenjuju da je najmanja vjerojatnost da će se suzdržati od pušenja obično one u kojima se pušenje zaista ponovo pojavljuje (Gwaltney i sur., 2009). Kod osoba koje same prekidaju pušenje viša percipirana samoefikasnost ima važnu ulogu u prelasku iz faze razmišljanja o prestanku pušenja $\mathrm{u}$ fazu prestanka te iz faze prestanka u fazu održavanja nepušenja (DiClemente i sur., 1985). Uz specifičnu samoefikasnost, istraživanja upućuju i na važnost varijabilnosti samoefikasnosti. Shiffman i suradnici (2000) su ispitivali dnevne varijacije samoefikasnosti tijekom mjesec dana nakon prestanka pušenja. Njihovi su rezultati pokazali da je prije ponovnog početka pušenja samoefikasnost visoka i stabilna, međutim, nakon toga ona opada i postaje nestabilna. Također, na osnovi dnevnih samoefikasnosti bilo je moguće značajno predvidjeti ponovni početak pušenja naredni dan. Nadalje, rezultati tog istraživanja pokazali su da su veće dnevne varijacije samoefikasnosti važne za održavanje ponovno započetog pušenja, čak i nakon kontrole generalizirane samoefikasnosti. Uz samostalni učinak, samoefikasnost značajno posreduje efekte nekih drugih varijabli na pušenje. Tako npr. Cinciripini i suradnici (2003) nalaze da niska samoefikasnost dva do četiri tjedna nakon prestanka pušenja posreduje efekte depresivnosti prije prestanka na ponovno pušenje. Rimal (2000) navodi da samoefikasnost posreduje odnos između znanja o zdravstvenim posljedicama određenih ponašanja i samih ponašanja. Kod osoba s višom samoefikasnošću postoji veća konzistencija između znanja i ponašanja, barem kada se radi o pušenju, zdravom načinu prehrane i tjelesnom vježbanju. Dakle, ovi nalazi pokazuju da kada postoji određeno znanje, tada viša samoefikasnost može olakšati njegovo prevođenje u ponašanje, što je vrlo važno kod programa usmjerenih na poboljšanje zdravstvenih ponašanja. Naime, nastojanja za poboljšanjem zdravstvenih ponašanja koja su usmjerena samo na povećanje znanja o njihovim zdravstvenim posljedicama mogu biti nedovoljna, a kod osoba niske samoefikasnosti i kontraproduktivna. Kod njih će takvo nastojanje prije izazvati stres zato što im niska percepcija vlastitih sposobnosti ne omogućava da usvojena znanja manifestiraju i u ponašanjima. Zbog toga je u takvim programima uz povećanje znanja nužno djelovati i na percipiranu samoefikasnost.

Dok je za pušenje relativno dobro dokazano da se na osnovi samoefikasnosti može predvidjeti apstinencija, barem kada se radi o relativno kratkotrajnim vremenskim periodima (Gwaltney i sur., 2009), rezultati istraživanja vezani uz alkoholizam nisu posve jednoznačni. Tako su npr. Rychtarik, Prue, Rapp i King (1992) našli da se tijekom tretmana odvikavanja od alkohola samoefikasnost značajno povećava, ali da njezina razina na kraju tretmana nije povezana s dužinom apstinencije. $\mathrm{Na}$ skupini alkoholičarki koje su prošle tromjesečni trening socijalnih vještina samoe- 
fikasnost je bila značajno povezana s apstinencijom tijekom tromjesečnog perioda, međutim ne i nakon osamnaest mjeseci (Rist i Watzl, 1983). Rezultati istraživanja češće ipak pokazuju povoljan učinak samoefikasnosti i kada se radi o alkoholizmu (Gilles, Turk i Fresco, 2006). Osobe s višom samoefikasnošću češće prisustvuju tretmanu odvikavanja, a one s višom samoefikasnošću za nekorištenjem alkohola u visoko-rizičnim situacijama za njegovo ponovno korištenje vjerojatnije će apstinirati tri, šest i dvanaest mjeseci nakon završetka tretmana (Goldbeck i sur., 1997). Niža samoefikasnost na kraju tretmana odvikavanja povezana je s kraćom apstinencijom i većom količinom konzumiranog alkohola tijekom jedne godine nakon završetka tretmana (McKay, Maisto i O'Farrell, 1993), pri čemu neka istraživanja pokazuju da dužinu apstinencije bolje predviđa veličina promjene samoefikasnosti tijekom tretmana odvikavanja nego razina samoefikasnosti na kraju tretmana (npr. Burling, Reilly, Moltzen i Ziff, 1989).

Pozitivni efekti samoefikasnosti dobiveni su i kod različitih drugih zdravstvenih ponašanja, kao što su tjelesna aktivnost tijekom kardiološke rehabilitacije (Blanchard, Arthur i Gunn, 2015), tjelesna aktivnost adolescenata (Peterson, Lawman, Wilson, Fairchild i Van Horn, 2013), pridržavanje propisane terapije kod oboljelih osoba (Archiopoli i sur., 2016; Nafradi, Nakamoto i Schulz, 2017), regulacija tjelesne težine (Clum, Rice, Broussard, Johnson i Webber, 2014), korištenje voća i povrća u prehrani (Kreausukon, Gellert, Lippke i Schwarzer, 2012), pušenje marihuane kod adolescenata (Walker, Neighbors, Rodriguez, Stephens i Roffman, 2011), vožnja u pijanom stanju (Wilson, Sheehan, Palk i Watson, 2016) itd. Zbog toga je percipirana samoefikasnost jedna od ključnih komponenti u različitim teorijama $i$ modelima zdravstvenog ponašanja.

Treba međutim napomenuti da viša samoefikasnost može imati i negativne zdravstvene posljedice. U intervencijama namijenjenim poboljšanju pridržavanja medicinskog tretmana povećanjem samoefikasnosti u nekoj specifičnoj ponašajnoj domeni, samoefikasnost često ne posreduje u toj povezanosti (Nafradi i sur., 2017; Sears i Stanton, 2001). Jedan od mogućih razloga je tzv. „sindrom lažne nade“ (Polivy i Herman, 2000), odnosno tendencija da ljudi podcjenjuju vrijeme, resurse i napor potreban za dolaženje do cilja. Takva inflatorna očekivanja, prisutnija kod osoba više samoefikasnosti, često rezultiraju neuspjesima pri pokušaju promjene ponašanja, što onda dovodi do osjećaja samookrivljavanja, frustracije i prestanka daljnjeg pokušavanja. Dodatno, osobe više samoefikasnosti mogu imati smanjenu anksioznost u pogledu medicinskog tretmana, odnosno sklonije su vjerovati da ga se ne treba striktno pridržavati (Rietveld i Koomen, 2002).

\section{ZAKLJUČAK}

Dosadašnja istraživanja u najvećoj mjeri govore o pozitivnim efektima samoefikasnosti na tjelesno zdravlje, međutim, neka od njih pokazuju da bi njezino djelova- 
nje na kardiovaskularno funkcioniranje i zdravstvena ponašanja u nekim uvjetima moglo dovesti i do negativnih zdravstvenih posljedica. Uz korištenje različitih uzoraka ispitanika, metodoloških postupaka i ishodnih varijabli, jedan od razloga nekonzistentnih nalaza jesu i korištene mjere samoefikasnosti. Naime, samoefikasnost je složen konstrukt koji ne varira samo s obzirom na specifičnost-generalnost, nego je potrebno razlikovati i različite tipove samoefikasnosti, kao što su npr. samoefikasnost suočavanja, samoefikasnost za tretirano ponašanje, samoefikasnost oporavka, samoefikasnost kontrole i samoefikasnost apstinencije (DiClemente, Fairhurst i Piotrowski, 1995). Ovi tipovi samoefikasnosti mogu imati različitu prediktivnu valjanost za različite vrste ishodnih varijabli tijekom različitih vremenskih točaka praćenja ispitanika. Nažalost, još uvijek nema istraživanja u kojima se tijekom različitih vremenskih točaka praćenja ispitanika koriste različite mjere specifične samoefikasnosti, a nedostaje nam i adekvatan teorijski okvir koji bi omogućio organizaciju različitih aspekata percepcije samoefikasnosti. Usprkos tome što većina istraživanja govori o važnosti specifičnih samoefikasnosti, neka upućuju i na važnost generalizirane samoefikasnosti. Međutim, još uvijek nam nije poznat točan odnos između generalizirane i specifičnih samoefikasnosti, niti njihova relativna važnost u različitim uvjetima. Nadalje, samoefikasnost je relativno visoko povezana s nekim drugim konstruktima važnim za zdravstvene ishode, kao što je npr. lokus kontrole (Kardum, Hudek-Knežević i Krapić, 2016), pa je pitanje u kojoj se mjeri dobiveni efekti mogu pripisati samoefikasnosti, a ne nekim drugim sličnim obilježjima ličnosti.

\section{LITERATURA}

Airlie, J., Baker, G.A., Smith, S.J. i Young, C.A. (2001). Measuring the impact of multiple sclerosis on psychosocial functioning: The development of new self-efficacy scale. Clinical Rehabilitation, 15, 259-265.

Ajzen, I. i Fishbein, M. (1977). Attitude-behavior relations: A theoretical analysis and review of empirical research. Psychological Bulletin, 84, 888-918.

Archiopoli, A., Ginossar, T., Wilcox, B., Avila, M., Hill, R. i Oetzel, J. (2016). Factors of interpersonal communication and behavioral health on medication self-efficacy and medication adherence. AIDS Care, 12, 1607-1614.

Aspinwall, L.G. i Taylor, S.E. (1992). Modeling cognitive adaptation: A longitudinal investigation of the impact of individual differences and coping on college adjustment and performance. Journal of Personality and Social Psychology, 63, 989-1003.

Bandura, A. (1977). Self-efficacy: Toward a unifying theory of behavioral change. Psychological Review, 84, 191-215.

Bandura, A. (2014). Exercise of personal agency through self-efficacy mechanism. U: R. Schwarzer (ur.), Self-efficacy: Thought control of action (str. 3-38). New York: Routledge. 
Bandura, A., Cioffi, D., Taylor, C.B. i Brouillard, M.E. (1988). Perceived self-efficacy in coping with cognitive stressors and opioid activation. Journal of Personality and Social Psychology, 55, 479-488.

Bandura, A., Reese, L. i Adams, N.E. (1982). Microanalysis of action and fear arousal as a function of different levels of perceived self-efficacy. Journal of Personality and Social Psychology, 43, 5-21.

Bandura, A., Taylor, C.B., Williams, S.L., Mefford, I.N. i Barchas, J.D. (1985). Catecholamine secretion as a function of perceived coping self-efficacy. Journal of Consulting and Clinical Psychology, 53, 406-414.

Banik, A., Schwarzer, R., Knoll, N., Czekierda, K. i Luszczynska, A. (2018). Self-efficacy and quality of life among people with cardiovascular diseases: A meta-analysis. Rehabilitation Psychology, 63, 295-312.

Bartholemew, L.K., Parcel, G.S., Swank, P.R. i Czyzewski, D.I. (1993). Measuring self-efficacy expectations for the self-management of cystic fibrosis. Chest, 103, 1524-1530.

Beckham, J.C., Burker, E.J., Lytle, B.L., Feldman, M.E. i Costakis, M.J. (1997). Self-efficacy and adjustment in cancer patients: A preliminary report. Behavioral Medicine, 23, 138-142.

Benight, C.C., Antoni, M., Kilbourn, K., Ironson, G., Fletcher, M., Redwine, L., Baum, A. i Schneiderman, N. (1997). Coping self-efficacy buffers psychological and physiological disturbances in HIV-infected men following a natural disaster. Health Psychology, 16, 248-255.

Benight, C.C., Freyaldenhoven, R., Hughes, J., Ruiz, J.M., Zoesche, T.A. i Lovallo, W. (2000). Coping self-efficacy and psychological distress following Oklahoma City bombing: A longitudinal analysis. Journal of Applied Social Psychology, 30, 1331-1344.

Benight, C.C. i Harper, M.L. (2002). Coping self-efficacy perception as a mediator between acute stress response and long term distress following natural disasters. Journal of Traumatic Stress, 15, 177-186.

Benight, C.C., Ironson, G., Carver, C.S., Wynings, C., Burnett, K., Greenwood, D., Schneiderman, N., Baum, A. i Klebe, K. (1999). Conservation of resources and coping selfefficacy predicting distress following a natural disaster: A causal model analysis where the environment meets the mind. Anxiety, Stress and Coping, 12, 107-126.

Besen, D.B. i Esen, A. (2012). Acceptance of illness and related factors in Turkish patients with diabetes. Social Behavior and Personality, 40, 1597-1610.

Blanchard, C., Arthur, H.M. i Gunn, E. (2015). Self-efficacy and outcome expectations in cardiac rehabilitation: Associations with women's physical activity. Rehabilitation Psychology, 60, 59-66.

Bonsaksen, T., Fagermonen, M.S. i Lerdal, A. (2014). Trajectories of self-efficacy inpersons with chronic illness: An explorative longitudinal study. Psychology and Health, 29, 350-364.

Brafford, L.J. i Beck, K.H. (1991). Development and validation of a condom self-efficacy scale for college students. Journal of American College Health, 39, 219-225.

Buckelew, S., Huyser, B., Hewett, J., Parker, J.C., Johnson, J.C., Conway, R. i Kay, D.R. (1996). Self-efficacy predicting outcome among fibromyalgia subjects. Arthritis Care and Research, 9, 97-104. 
Buckelew, S.P., Murray, S.E., Hewett, J.E., Johnson, J. i Huyser, B. (1995). Self-efficacy, pain, and physical activity among fibromyalgia subjects. Arthritis Care and Research, $8,43-50$.

Burling, T.A., Reilly, P.M., Moltzen, J.O. i Ziff, D.C. (1989). Self-efficacy and relapse among inpatient drug and alcohol abusers: A predictor of outcome. Journal of Studies on Alcohol, 50, 354-360.

Carroll, D.L. (1995). The importance of self-efficacy expectations in elderly patients recovering from coronary artery bypass surgery. Heart and Lung: Journal of Critical Care, 24, 50-59.

Caserta, M.T., Wyman, P.A., Wang, H., Moynihan, J. i O’Connor, T.G. (2011). Associations among depression, perceived self-efficacy, and immune function and health in preadolescent children. Development and Psychopathology, 23, 1139-1147.

Casier, A., Goubert, L., Gebhardt, W.A., De Baets, F., Van Aken, S. i Crombez, G. (2013). Acceptance, well-being and goals in adolescents with chronic illness: A daily process analysis. Psychology and Health, 28, 1337-1351.

Cervone, D.L. (2000). Thinking about self-efficacy. Behavior Modification, 24, 30-56.

Cheever, K.H. i Hardin, S.B. (1999). Effects of traumatic events, social support, and selfefficacy on adolescents' self-health assessments. Western Journal of Nursing Research, 21, 673-684.

Chemers, M.M., Hu, L.T. i Garcia, B.F. (2001). Academic self-efficacy and first-year college student performance and adjustment. Journal of Educational Psychology, 93, 55-64.

Chesney, M.A., Chambers, D.B., Ickovics, J.R., Gifford, A.L., Neidig, J., Zwickl, B. i Wu, A.W. (2000). Self-reported adherence to antiretroviral medications among participants in HIV clinical trials: The AACTG adherence instruments. AIDS Care, 12, 255-266.

Cinciripini, P., Wetter, D.W., Fouladi, R.T., Blalock, J.A., Carter, B.L., Cinciripini, L.G. i Baile, W.F. (2003). The effects of depressed mood on smoking cessation: Mediation by post-cessation self-efficacy. Journal of Consulting and Clinical Psychology, 71, 292301.

Clum, G.A., Rice, J.C., Broussard, M., Johnson, C.C. i Webber, L.S. (2014). Associations between depressive symptoms, self-efficacy, eating styles, exercise and body mass index in women. Journal of Behavioral Medicine, 37, 577-586.

Cozzarelli, C. (1993). Personality and self-efficacy as predictors of coping with abortion. Journal of Personality and Social Psychology, 65, 1224-1236.

Craig, A.R., Bartrop, R., Lal, S.K.L., Henderson, R.J., Hart, M. i Hunyor, S. (2001). Optimizing blood pressure reduction: Predicting success in the home environment. Clinical Psychology and Psychotherapy, 8, 33-40.

Dalgard, F., Stern, R., Lien, L. i Hauser, S. (2012). Itch, stress and self-efficacy among 18-year-old boys and girls: A Norwegian population-based cross-sectional study. Acta Dermato-Venereologica, 92, 547-552.

DiClemente, C.C., Fairhurst, S.K. i Piotrowski, N.A. (1995). Self-efficacy and addictive behaviors. U: J.E. Maddux (ur.), Self-efficacy, adaptation, and adjustment: Theory, research, and application (str. 109-141). New York: Plenum Press.

DiClemente, C.C., Prochaska, J.O. i Gibertini, M. (1985). Self-efficacy and the stages of self-change of smoking. Cognitive Therapy and Research, 9, 181-200. 
Dwyer, K.A. (1997). Psychosocial factors and health status in women with rheumatoid arthritis: Predicitive models. American Journal of Preventive Medicine, 13, 66-72.

Edwards, R., Telfair, J., Cecil, H. i Lenoci, J. (2001). Self-efficacy as a predictor of adult adjustment to sickle cell disease: One-year outcomes. Psychosomatic Medicine, 63, 850-858.

Elizur, Y. i Hirsh, E. (1999). Psychosocial adjustment and mental health two months after coronary artery bypass surgery: A multisystemic analysis of patients' resources. Journal of Behavioral Medicine, 22, 157-177.

Emme, C., Mortensen, E.L., Rydahl-Hansen, S., Ostergaard, B. i Phanareth, K. (2012). Danish version of „The COPD self-efficacy scale“: Translation and psychometric properties. Scandinavian Journal of Caring Sciences, 26, 615-623.

Endler, N.S., Kocovski, N.L. i Macrodimitris, S.D. (2001). Coping, efficacy, and perceived control in acute vs chronic illnesses. Personality and Individual Differences, 30, 617625.

Ewart, C.K., Taylor, C.B., Reese, L.B. i DeBusk, R.F. (1983). The effects of early postmyocardial infarction exercise testing on self-perception and subsequent physical activity. American Journal of Cardiology, 51, 1076-1080.

Findley, J.C., Kerns, R., Weinberg, L.D. i Rosenberg, R. (1998). Self-efficacy as a psychological moderator of chronic fatigue syndrome. Journal of Behavioral Medicine, 21, 351-362.

Fitzgerald, S.T., Becker, D.M., Celentano, D.D., Swank, R. i Brinker, R. (1989). Return to work after percutaneous transluminal coronary angioplasty. American Journal of Cardiology, 64, 1108-1112.

Fry, P.S. (2003). Perceived self-efficacy domains as predictors of fear of the unknown and fear of dying among older adults. Psychology and Aging, 18, 474-486.

Gattuso, S.M., Litt, M.D. i Fitzgerald, T.E. (1992). Coping with gastrointestinal endoscopy: Self-efficacy enhancement and coping style. Journal of Consulting and Clinical Psychology, 60, 133-139.

Gerin, W., Litt., M.D., Deich, J. i Pickering, T.G. (1995). Self-efficacy as a moderator of perceived control effects on cardiovascular reactivity: Is enhanced control always beneficial. Psychosomatic Medicine, 57, 390-397.

Gerin, W., Litt., M.D., Deich, J. i Pickering, T.G. (1996). Self-efficacy as a component of active coping: Effects on cardiovascular reactivity. Journal of Psychosomatic Research, 40, 485-493.

Gilles, D.M., Turk, C.L. i Fresco, D.M. (2006). Social anxiety, alcohol expectancy and selfefficacy as predictors of heavy drinking in college students. Addictive Behaviors, 31, 388-98.

Goldbeck, R., Myatt, P. i Aitchison, T. (1997). End-of-treatment self-efficacy: a predictor of abstinence. Addiction, 92, 313-324.

Gortner, S.R. i Jenkins, L.S. (1990). Self-efficacy and activity level following cardiac surgery. Journal of Advanced Nursing, 15, 1132-1138.

Guidi, L., Tricerri, A., Vangeli, M., Frasca, D., Errani, A.R., Di Giovanni, A., Antico, L., Menini, E., Sciamanna, V., Magnavita, N., Dorita, G. i Bartoloni, C. (1999). Neuropep- 
tide Y plasma levels and immunological changes during academic stress. Neuropychobiology, 40, 188-195.

Gwaltney, C.J., Metrik, J., Kahler, CW. i Shiffman, S. (2009). Self-efficacy and smoking cessation: A meta-analysis. Psychology of Addictive Behaviors, 23, 56-66.

Hartley, S.M., Vance, D.E., Elliott, T.R., Cuckler, J.M. i Berry, J.W. (2008). Hope, self-efficacy, and functional recovery after knee and hip replacement surgery. Rehabilitation Psychology, 53, 521-529.

Higgins, T.E. i Scholer, A.A. (2008). When is personality revealed? A motivated cognition approach. U: O.P., John, R.W., Robins, L.A., Pervin (ur.), Handbook of personality: Theory and research (str. 182-207). New York: The Guilford Press.

Hilmert, C.J., Christenfeld, N. i Kulik, J.A. (2002). Audience status moderates the effects of social support and self-efficacy on cardiovascular reactivity during public speaking. Annals of Behavioral Medicine, 24, 122-131.

Hobfoll, S.E., London, P. i Orr, E. (1988). Mastery, intimacy, and stress resistance during war. Journal of Community Psychology, 16, 317-331.

Horn, W., Yoels, W., Wallace, D., Macrina, D. i Wrigley, M. (1998). Determinants of seIf-efficacy among persons with spinal cord injuries. Disability and Rehabilitation, 20, $138-141$.

Hudek-Knežević, J. i Kardum, I. (2006). Psihosocijalni aspekti tjelesnog zdravlja: I: Stress i tjelesno zdravlje. Jastrebarsko: Naklada Slap.

Hudek-Knežević, J. i Kardum, I. (2009). Five-factor personality dimensions and 3 healthrelated personality constructs as predictors of health. Croatian Medical Journal, 50, 394-402.

Ironson, G., Weiss, S., Lydston, D., Ishii, M., Jones, D., Asthana, D., Tobin, J., Lechner, S., Laperriere, A., Schneiderman, N. i Antoni, M. (2005). The impact of improved self-efficacy on HIV viral load and distress in culturally diverse women living with AIDS: The SMART/EST women's project. AIDS Care, 17, 222-236.

Jex, S.M. i Bliese, P.D. (1999). Efficacy beliefs as a moderator of the effects of work related stressors. A multilevel study. Journal of Applied Psychology, 85, 349-361.

Jex, S.M., Bliese, P.D., Buzzell, S. i Primeau, J. (2001). The impact of self-efficacy on stressor-strain relations: Coping style as an explanatory mechanism. Journal of Applied Psychology, 86, 401-409.

Kalichman, S.C., Rompa, D., DiFonzo, K., Simpson, D., Kyomugisha, F., Austin, J. i Luke, W. (2001). Initial development of scales to assess self-efficacy for disclosing HIV status and negotiating safer sex in HIV-positive persons. AIDS and Behavior, 5, 291-296.

Kaplan, R.M., Ries, A.L., Prewitt, L.M. i Eakin, E. (1994). Self-efficacy expectation predicts survival for patients with chronic obstructive pulmonary disease. Health Psychology, 13, 366-368.

Karademas, E.C. i Kalantzi-Azizi, A. (2004). The stress process, self-efficacy expectations, and psychological health. Personality and Individual Differences, 37, 1033-1034.

Kardum, I. i Hudek-Knežević, J. (2008). Konceptualni i metodološki problemi u ispitivanjima odnosa ličnosti i tjelesnog zdravlja. Društvena istraživanja, 18, 3-24. 
Kardum, I. i Hudek-Knežević, J. (2012). Relationships between five-factor personality traits and specific health-related personality dimensions. International Journal of Clinical and Health Psychology, 12, 373-387.

Kardum, I., Hudek-Knežević, J. i Krapić, N. (2016). Lokus kontrole i tjelesno zdravlje. Klinička psihologija, 9, 271-292.

Kasen, S., Vaughan, R.D. i Walter, H.J. (1992). Self-efficacy for AIDS preventive behaviors among tenth grade students. Health Education Quarterly, 19, 187-202.

Keoske, G.F., Kirk, S.A. i Keoske, R.D. (1993). Coping with job stress: Which strategies work best? Journal of Occupational and Organizational Psychology, 66, 319-335.

Kraaij, V., Garnefski, N., Schroevers, M.J., van der Veek, S.M.C., Witlox, R. i Maes, S. (2008). Cognitive coping, goal self-efficacy and personal growth in HIV-infected men who have sex with men. Patient Education and Counseling, 72, 301-304.

Krapić, N., Hudek-Knežević, J. i Kardum, I. (2015). Stres on adolescence: Effects on development. U: J.D. Wright (ur.), International encyclopedia of social and behavioral sciences (str. 562-569). Oxford: Elsevier.

Kreausukon, P., Gellert, P., Lippke, S. i Schwarzer, R. (2012). Planning and self-efficacy can increase fruit and vegetable consumption: A randomized controlled trial. Journal of Behavioral Medicine, 35, 443-451.

Lackner, J.M., Carosella, A.M. i Feuerstein, M. (1996). Pain expectancies, pain, and functional self-efficacy expectancies as determinants of disability in patients with chronic low back disorders. Journal of Consulting and Clinical Psychology, 64, 212-220.

Lazarus, R.S. i Folkman, S. (1984). Stress, appraisal, and coping. New York: Springer.

Light, K.C., Sherwood, A. i Turner, J.R. (1992). High cardiovascular reactivity to stress: A predictor of later hypertension development. U: J.R. Turner, A. Sherwood, K.C. Light (ur.), Individual differences in cardiovascular responses to stress (str. 281-293). New York: Plenum.

Lorig, K. i Gonzalez, V. (1992). The integration of theory with practice: A 12-year case study. Health Education Quarterly, 19, 355-368.

Lorig, K., Chastain, R., Ung, E., Shoor, S. i Holman, H. (1989). Development and evaluation of a scale to measure perceived self-efficacy in people with arthritis. Arthritis and Rheumatism, 32, 37-44.

Luszczynska, A., Benight, C.C. i Cieslak, R. (2009). Self-efficacy and health-related outcomes of collective trauma: A systematic review. European Psychologist, 14, 51-62.

Luszczynska, A., Benight, C.C., Cieslak, R., Kissinger, P., Reilly, K.H. i Clark, R.A. (2009). Self-efficacy mediates effects of exposure, loss of resource, and life stress on posttraumatic distress among trauma survivors. Applied Psychology: Health and Well-Being, 1, 73-90.

Luszczynska, A., Scholz, U. i Schwarzer, R. (2002). The general self-efficacy scale: Multicultural validation studies. The Journal of Psychology, 139, 439-457.

Maddux, J.E. i Gosselin, J. T. (2012). Self-efficacy. U: M.R. Leary, J.P. Tangney (ur.), Handbook of self and identity (str. 198-224). New York: The Guilford Press.

Maddux, J.E. i Volkmann, J. (2010). Self-efficacy. U: R.H. Hoyle (ur.), Handbook of personality and self-regulation (str. 315-331). Chichester: Wiley-Blackwell. 
Major, B., Cozzarelli, C., Sciacchitano, A.M., Cooper, M.L., Testa, M. i Mueller, P.M. (1990). Perceived social support, self-efficacy, and adjustment to abortion. Journal of Personality and Social Psychology, 59, 452-463.

Manning, M.M. i Wright, T.L. (1983). Self-efficacy expectancies, outcome expectancies, and the persistence of pain control in childbirth. Journal of Personality and Social Psychology, 45, 421-431.

Marcus, B. H., Selby, V.C., Niaura, R.S. i Rossi, J.S. (1992). Self-efficacy and the stages of exercise behavior change. Research Quarterly for Exercise and Sport, 63, 60-66.

Marino, P., Sirey, R.A., Raue, P.J. i Alexopoulos, G.S. (2008). Impact of social support and self-efficacy on functioning in depressed older adults with chronic obstructive pulmonary disease. International Journal of COPD, 3, 713-718.

Marks, R. (2001). Efficacy theory and its utility in arthritis rehabilitation: Review and recommendations. Disability and Rehabilitation, 23, 271-280.

Matsushima, R. i Shiomi, K. (2003). Social self-efficacy and interpersonal stress in adolescence. Social Behavior and Personality, 31, 323-332.

McKay, J.R., Maisto, S.A. i O'Farrell, T.J. (1993). End-of-treatment self-efficacy, aftercare, and drinking outcomes of alcoholic men. Alcoholism: Clinical and Experimental Research, 17, 1078-1083.

Mendes de Leon, C.F., Seeman, T.E., Baker, D.I., Richardson, E.D. i Tinetti, M.E. (1996). Self-efficacy, physical decline, and change in functioning in community-living elders: A prospective study. Journal of Gerontology: Social Sciences, 51, 183-190.

Miller, C. i Cronan, T. (1998). The effects of coping style and self-efficacy on health status and health care costs. Anxiety, Stress and Coping, 11, 311-325.

Murphy, S. (1987). Self-efficacy and social support mediators of stress on mental health following a natural disaster. Western Journal of Nursing Research, 9, 58-86.

Nafradi, L., Nakamoto, K. i Schulz, P.J. (2017). Is patient empowerment the key to promote adherence? A systematic review of the relationship between self-efficacy, health locus of control and medication adherence. PLOS ONE, https://doi.org/10.1371/journal. pone. 0186458 .

O'Leary, A., Jemmott, L.S. i Jemmott, J.B. (2008). Mediation analysis of an effective sexual risk-reduction intervention for women: The importance of self-efficacy. Health Psychology, 27, S180-S184.

O’Hea, E.L., Moon, S., Grothe, K.B., Boudreaux, E., Bodenlos, J.S., Wallston, K. i Brantley, P.J. (2009). The interaction of locus of control, self-efficacy, and outcome expectancy in relation to $\mathrm{HbA1c}$ in medically underserved individuals with type 2 diabetes. Journal of Behavioral Medicine, 32, 106-117.

O'Leary, A. (1992). Self-efficacy and health: Behavioral and stress-physiological mediation. Cognitive Therapy and Research, 16, 229-245.

O'Leary, A. (2001). Social-cognitive theory mediators of behavior change in the National Institute of Mental Health multisite HIV prevention trial. Health Psychology, 20, 369376.

O'Leary, A., Shoot, S., Lorig, K. i Holman, H. (1988). A cognitive-behavioral treatment for rheumatoid arthritis. Health Psychology, 7, 527-544. 
Orbell, S., Johnson, M., Rowley, D., Davey, P. i Espley, A. (2001). Self-efficacy and goal importance in the prediction of physical disability in people following hospitalization: A prospective study. British Journal of Health Psychology, 6, 25-40.

Park, H.I. i Lee, H. (2015). The effects of recovery-related self-efficacy on occupational health among korean workers. International Journal of Stress Management, 22, 372-394.

Parsons, J.T., Rosof, E. i Mustanski, B. (2008). Medication adherence mediates the relationship between adherence self-efficacy and biological assessments of HIV health among those with alcohol use disorders. AIDS and Behavior, 12, 95-103.

Peterson, M.S., Lawman, H.G., Wilson, D.K., Fairchild, A. i Van Horn, M.L. (2013). The association of self-efficacy and parent social support on physical activity in male and female adolescents. Health Psychology, 32, 666-674.

Polivy, J. i Herman, C.P. (2000). The false-hope syndrome: Unfulfilled expectations for selfchange. Current Directions in Psychological Science, 9, 128-131.

Reid, A.E. i Aiken, L.S. (2011). Integration of five health behaviour models: Common strengths and unique contributions to understanding condom use. Psychology and Health, 26, 1499-1520.

Rejeski, W.J., Craven, T., Ettinger, W.H., McFarlane, M. i Shumaker, S. (1996). Self-efficacy and pain in disability with osteoarthritis of the knee. Journal of Gerontology: Psychological Sciences, 51, 24-29.

Riazi, A., Thompson, A.J. i Hobart, J.C. (2004). Self-efficacy predicts self-reported health status in multiple sclerosis. Multiple Sclerosis, 10, 61-66.

Rietveld, S. i Koomen, J.M. (2002). A complex system perspective on medication compliance: Information for healthcare providers. Dis Manage Health Outcomes, 10, 621-630.

Rimal, R.N. (2000). Closing the knowledge - behavior gap in health promotion: The mediating role of self-efficacy. Health Communication, 12, 219-237.

Rippetoe, P.A. i Rogers, R.W. (1987). Effects of components of protection-motivation theory on adaptive and maladaptive coping with a health threat. Journal of Personality and Social Psychology, 53, 596-604.

Rist, F. i Watzl, H. (1983). Self assessment of relapse risk and assertiveness in relation to treatment outcome of female alcoholics. Addictive Behaviors, 8, 121-127.

Roddenberry, A. i Renk, K. (2010). Locus of control, and self-efficacy: potential mediators of stress, illness, and utilization of health services in college students. Child Psychiatry and Human Development, 41, 353-370.

Rottmann, N., Dalton, S.O., Christensen, J., Frederiksen, K. i Johansen, C. (2010). Self-efficacy, adjustment style, and well-being in breast cancer patients: A longitudinal study. Quality of Life Research, 19, 827-836.

Rychtarik, R.G., Prue, D.M., Rapp, S.R. i King, A.C. (1992). Self-efficacy, aftercare and relapse in a treatment program for alcoholics. Journal of Studies on Alcohol, 53, 435-440.

Sanz, A. i Villamarin, F. (2001). The role of perceived control in physiological reactivity: Self-efficacy and incentive value as regulators of cardiovascular adjustment. Biological Psychology, 56, 219-246.

Sarkar, U., Ali, S. i Whooley, M.A. (2009). Self-efficacy as a marker of cardiac function and predictor of heart failure hospitalization and mortality in patients with stable coronary heart disease: Findings from the Heart and Soul Study. Health Psychology, 28, 166-173. 
Schaubroeck, J., Jones, J.R. i Xie, J.L. (2001). Individual differences in utilizing control to cope with job demands: Effects on susceptibility to infectious disease. Journal of Applied Psychology, 86, 265-278.

Schaubroeck, J. i Merritt, D.E. (1997). Divergent effects of job control on coping with work stressors: The key role of self-efficacy. Academy of Management Journal, 40, 738-754.

Schiaffino, K.M., Revenson, T.A. i Gibofsky, A. (1991). Assessing the impact of self-efficacy beliefs on adaptation to rheumatoid arthritis. Arthritis Care and Research 4, 150157.

Schmitt, M.M., Goverover, Y., DeLuca, J. i Chiaravalotti, N. (2014). Self-efficacy as a predictor of self-reported physical, cognitive, and social functioning i multiple sclerosis. Rehabilitation Psychology, 59, 27-34.

Schneider, J.A., O’Leary, A. i Agras, W.S. (1987). The role of perceived self-efficacy in recovery from bulimia: A preliminary examination. Behavior Research and Therapy, $25,429-432$.

Scholz, U., Dona, B. G., Sud, S. i Schwarzer, R. (2002). Is general self-efficacy a universal construct? European Journal of Psychological Assessment, 18, 242-251.

Schwarzer, R. i Fuchs, R. (1996). Self-efficacy and health behaviors. U: M. Conner, P. Norman (ur.), Predicting health behaviour: Research and practice with social cognition models (str. 163-196). Buckingham: Open University Press.

Schwarzer, R. i Jerusalem, M. (1995). Generalized self-efficacy scale. U: J. Weinman, S. Wright, M. Johnston (ur.), Measures in health psychology: A user's portfolio. Causal and control beliefs (str. 35-37). Windsor, UK: NFER-NELSON.

Schwarzer, R. i Renner, B. (2000). Social-cognitive predictors of health behavior: Action self-efficacy and coping self-efficacy. Health Psychology, 19, 487-495.

Schwerdtfeger, A., Konermann, L. i Schonhofen, K. (2008). Self-efficacy as a health-protective resource in teachers? A biopsychosocial approach. Health Psychology, 27, 358-368.

Sears, S.R. i Stanton, A.L. (2001). Expectancy-value constructs and expectancy violation as predictors of exercise adherence in previously sedentary women. Health Psychology, 20, 326-333.

Seeman, M. i Seeman, T. (1983). Health behavior and personal autonomy. A longitudinal study of the sense of control illness. Journal of Health and Social Behavior, 24, 144-160.

Shavit, Y. i Martin, F.C. (1987). Opiates, stress, and immunity: Animal studies. Annals of Behavioral Medicine, 9, 11-20.

Shelton, S.H. (1990). Developing the construct of general self-efficacy. Psychological Reports, 66, 987-994.

Shiffman, S., Balabanis, M.H., Paty, J.A., Engberg, J., Gwaltney, C.J., Liu, K.S., Gnys, M., Hickcox, M. i Paton, S.M. (2000). Dynamic effects of self-efficacy on smoking lapse and relapse. Health Psychology, 19, 315-323.

Shoji, K., Cieslak, R., Smoktunowicz, E., Rogala, A., Benight, C.C. i Luszczynska, A. (2016). Associations between job burnout and self-efficacy: A meta-analysis. Anxiety, Stress and Coping, 29, 367-386.

Simpson, E. i Jones, M. (2013). An exploration of self-efficacy and self-management in COPD patients. British Journal of Nursing, 22, 1105-1109. 
Solomon, Z., Benbenishty, R. i Mikulincer, M. (1991). The contribution of wartime, pre-war, and post-war factors on self-efficacy: A longitudinal study of combat stress reaction. Journal of Traumatic Stress, 4, 345-361.

Steca, P., Greco, A., D’Addario, M., Monzani, D., Pozzi, R., Villani, A., Rella, V., Giglio, A., Malfatto, G. i Parati, G. (2013). Relationship of illness severity with health and life satisfaction in patients with cardiovascular disease: The mediating role of self-efficacy beliefs and illness perceptions. Journal of Happiness Studies, 14, 1585-1599.

Stockman, A.F. i Altmaier, E.M. (2001). Relation of self-efficacy to reported pain and pain medication usage during labor. Journal of Clinical Psychology in Medical Settings, 8, 161-166.

Stotland, S, i Zuroff, D.C. (1991). Relations between multiple measures of dieting selfefficacy and weight change in a behavioral weight control program. Behavior Therapy, 22, 47-59.

Sullivan, M.D., LaCroix, A.Z., Russo, J. i Katon, W.J. (1998). Self-efficacy and self-reported functional status in coronary heart disease: A six-month prospective study. Psychosomatic Medicine, 60, 473-478.

Taylor, C.B., Bandura, A., Ewart, C.K., Miller, N.H. i DeBusk, R.F. (1985). Raising spouses' and patient's perception of his cardiac capabilities after clinically uncomplicated myocardial infarction. American Journal of Cardiology, 55, 635-638.

Tedman, S., Thornton, E. i Baker, G.A. (1995). Development of a scale to measure core beliefs and perceived self-efficacy in adults with epilepsy. Seizure, 4, 221-231.

Teng, Y. i Mak, W.W.S. (2011). The role of planning and self-efficacy in condom use among men who have sex with men: An application of the health action process approach model. Health Psychology, 30, 119-128.

Terry, D. (1994). Determinants of coping: The role of stable and situational factors. Journal of Personality and Social Psychology, 66, 895-910.

The NIMH Multisite HIV Prevention Trial Group. (2001). Social-cognitive theory mediators of behavior change in the National Institute of Mental Health multisite HIV prevention trial. Health Psychology, 20, 369-376.

van den Heuvel, E.T.P., de Witte, L.P., Schure, L.M., Sanderman, R. i de Jong, B.M. (2001). Risk factors for burn-out in caregivers of stroke patients, and possibilities for interventions. Clinical Rehabilitation, 16, 669-677.

Waldrop, D., Lightsey, O.R., Ethington, C.A., Woemmel, C.A. i Coke, A.L. (2001). Selfefficacy, optimism, health competence, and recovery from orthopedic surgery. Journal of Counseling Psychology, 48, 233-238.

Walker, D.D., Neighbors, C., Rodriguez, L.M., Stephens, R.S. i Roffman, R.A. (2011). Social norms and self-efficacy among heavy using adolescent marijuana smokers. Psychology of Addictive Behaviors, 25, 727-732.

Weitlauf, J.C., Smith, R.E. i Cervone, D. (2000). Generalization effects of coping-skills training: Influence of self-defense training on women's efficacy beliefs, assertiveness, and aggression. Journal of Applied Psychology, 85, 625-633.

Wiedenfeld, S.A., O’Leary, A., Bandura, A., Brown, S., Levine, S. i Raska, K. (1990). Impact of perceived self-efficacy in coping with stressors on components of the immune system. Journal of Personality and Social Psychology, 59, 1082-1094. 
Wilson, H., Sheehan, M., Palk, G. i Watson, A. (2016). Self-efficacy, planning, and drink driving: Applying the health action process approach. Health Psychology, 35, 695-703.

Woods, T.E., Antoni, M.H., Ironson, G.H. i Kling, D.W. (1999). Religiosity is associated with affective and immune status in symptomatic HIV-infected gay men. Journal of Psychosomatic Research, 46, 165-176.

Wortman, C.B. i Dunkel-Schetter, C. (1979). Interpersonal relations and cancer: A theoretical analysis. Journal of Social Issues, 35, 120-155.

Wright, R.A. i Dismukes, A. (1995). Cardiovascular effects of experimentally induced efficacy (ability) appraisals at low and high levels of avoidant task demand. Psychophysiology, 32, 172-176.

Yang, N., Xiao, H., Wang, W., Li, S., Yan, H. i Wang, Y. (2018). Effects of doctors' empathy abilities on the cellular immunity of patients with advanced prostate cancer treated by orchiectomy: The mediating role of patients' stigma, self-efficacy and anxiety. Patient Preference and Adherence, 12, 1305-314.

\title{
THE RELATIONSHIPS OF SELF-EFFICACY AND PHYSICAL HEALTH: EFFECTS AND MECHANISMS
}

\begin{abstract}
The effects of self-efficacy on various aspects of physical health as well as the basic mechanisms through which self-efficacy may exert its effects on physical health are presented in this article. Theoretical bases of self-efficacy and the measurement of generalized and specific self-efficacies are described. Furthermore, the most important empirical results on the effects of self-efficacy on different aspects of physical health are presented. From the mechanisms through which self-efficacy exercises its effects on physical health, we described its effects on cardiovascular and immunological functioning, stress experience, coping with stress and health behaviors. Although higher self-efficacy usually has positive effects on physical health, we presented research showing that higher self-efficacy through its effects on cardiovascular functioning and health behaviors may exert potentially negative effects on physical health. We also presented some most important directions for future research on the relationship between self-efficacy and physical health.
\end{abstract}

Keywords: self-efficacy, physical health, health behavior, coping with stress 